\title{
ESTRUTURA GENÉTICA DE POPULAÇÕES NATURAIS DE Syagrus romanzoffiana (ARECACEAE) DO CONTINENTE (SERRA DO MAR, S.P.) E DA ILHA DOS ALCATRAZES
}

\author{
MARTA ORGANO NEGRÃO \\ Engenheira Florestal
}

Orientador: Prof. Dr. PAULO YOSHIO KAGEYAMA

Dissertação apresentada à Escola Superior de Agricultura "Luiz de Queiroz", Universidade de São Paulo, para obtenção do título de Mestre em Agronomia, área de Concentração: Genética e Melhoramento de Plantas

PIRACICABA

Estado de São Paulo - Brasil

Outubro- 1999 
Dados Internacionais de Catalogação na Publicação (CIP) DIVISÃO DE BIBLIOTECA E DOCUMENTAÇÃO - Campus "Luiz de Queiroz"/USP

\author{
Negrão, Marta Organo \\ Estrutura genética de populaçōes naturais de Syagrus romanzoffiana (Arecaceae) do \\ continente (Serra do Mar, S.P.) e da ilha dos Alcatrazes / Marta Organo Negrāo. - - Piracicaba, \\ 1999. \\ $78 \mathrm{p}$. \\ Dissertação (mestrado) - Escola Superior de Agricultura Luiz de Queiroz, 1999. \\ Bibliografia. \\ 1. Diversidade genética 2. Espécie florestal nativa 3. Genética de população 4. Isoenzima 5. \\ Palmeira I. Título
}

CDD 634.6

Qpermitida a copa total ou parcial deste docamento, desde que citada a fonte -0 ator 
A Terra será o que são seus homens. provérbio Asteca

Não jogue fora a semente feia, pois vocè também estará jogando fora as flores contidas nela Osho 
Dedico à minha mãe e ao meu pai que sempre me deixaram livre para escolher o meu caminho, e à Taís (in memorian), com saudades.

Aos meus grandes amigos, verdadeiros companheiros de vida, eu ofereço. 


\section{AGRADECIMENTOS}

Ao Paulo Kageyama pela orientação e por ter me dado a oportunidade de trabalhar em seu laboratório.

Ao prof. Vencovsky pela discussão em genética de populações e pela revisão do summary.

Ao Projeto Alcatrazes, da Sociedade de Defesa do Litoral Brasileiro, pela viabilização da expedição à Ilha. Os meus mais caros ậradecimentos a Fausto Pires Campos pelo incansável apoio e amizade. antes, durante e depois da expedição.

Ao Parque da Serra do Mar (núcleos Cubatão e São Sebastião), em especial a Edson Lobato (Fredê), pelo alojamento e ajuda em campo.

Às pousadas Solar de Camburi (Camburi) e Alto da Serra (Caraguatatuba) pela estadia.

A Rogério Hilf de Moraes pelo transporte à Ilha dos Alcatrazes.

Ao CNPq pela concessão de bolsa de estudos.

Ao Flávio, por ter me ajudado em todas as etapas com a maior paciência e disponibilidade. desde a lidar com o pHmetro até as discussões em conservação genética. Agradeço também pela leitura critica e sugestões.

Ao Alexandre pelo imensurável auxilio com os programas estatiscos.

A todos no LARGEA. pela ajucia em laboratório e discussões teóricas. e principalmente pelo companheirismo. em especial a Helena. Lina. Bia e Edu que me acompanharam nas etapas iniciais e mais dificeis.

Ao Gelson. do LARGEA. e Léa. da Genética. pelo esforço muito além do que deveriam.

Ao Eduardo. pela ajuda nas viagens a campo e pelas fotografias, e por sempre me dar força para continuar.

Às meninas de casa. Pan. Val. Chipe. Kanta. Guavira. Sorriso. Aru. e mais recentemente Carla e Patrícia. que me apoiaram e incentivaram durante o percurso. pelo carinho e amizade.

A minha mãe (Edi), a Lurdinha e Carol. ao meu pai (Lisias) por aguentarem as minhas ausências. pelo amor e conforto sempre presentes. 


\section{SUMÁRIO}

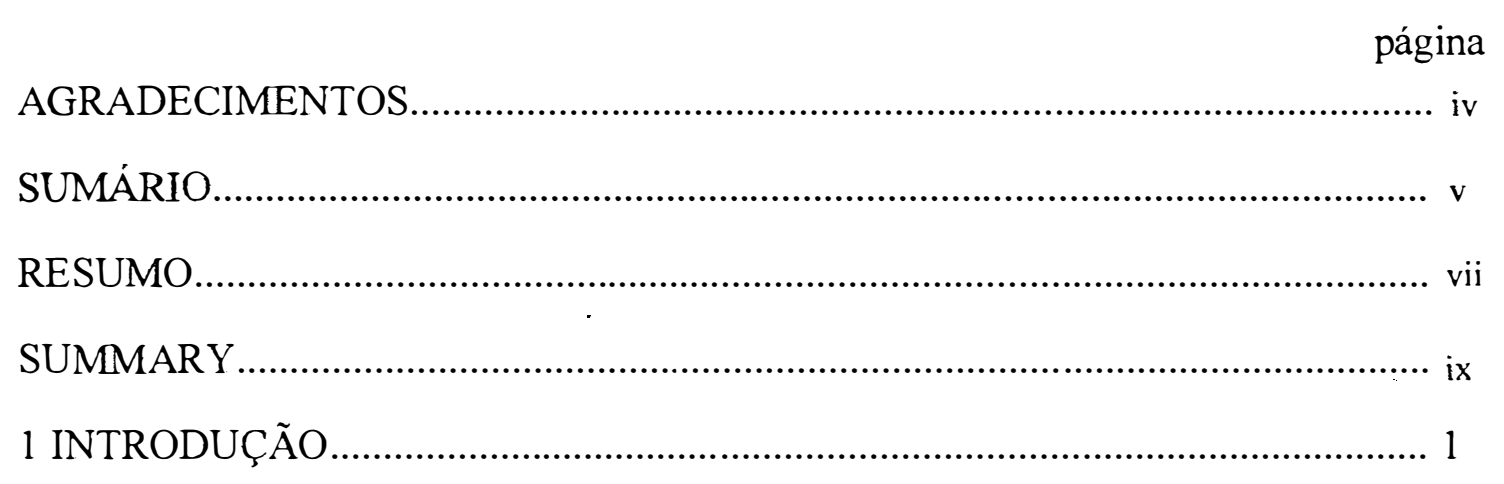

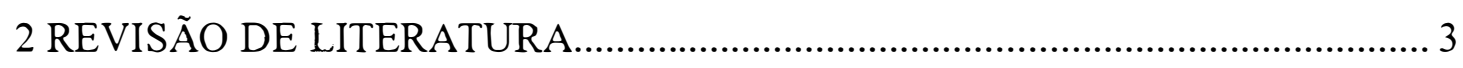

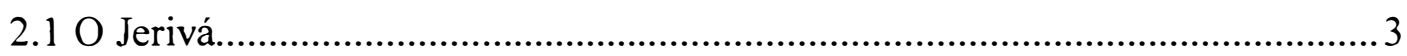

2.2 Considerações gerais sobre as palmeiras...................................................... 6

2.3 Estrutura genética e sistema reprodutivo de espécies arbóreas tropicais.......... 9

2.4 Efeitos genéticos em populações pequenas e/ou isoladas................................... 14

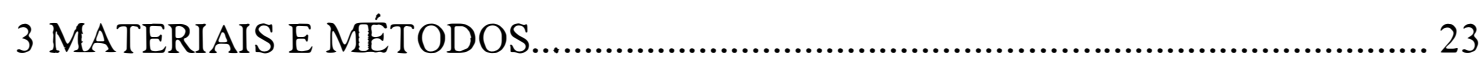

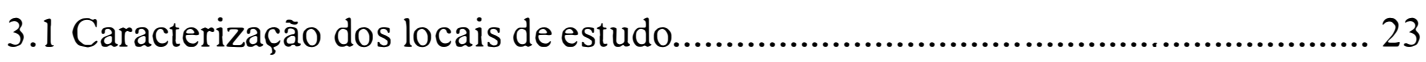

3.2 Populações estudadas e coleta do material....................................................... 24

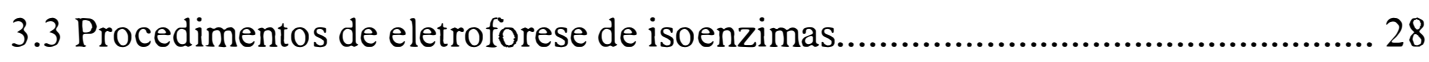

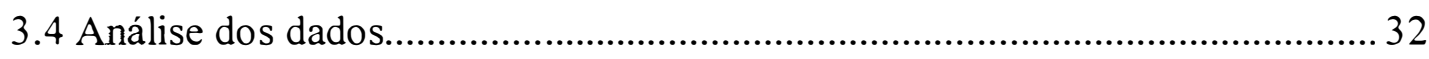

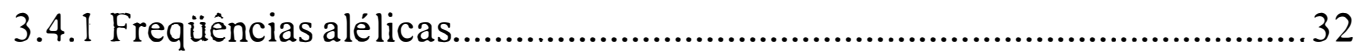

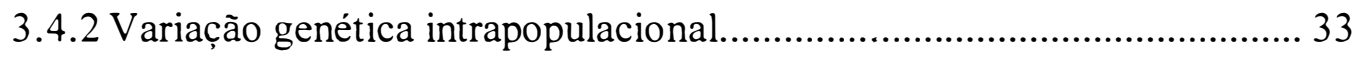

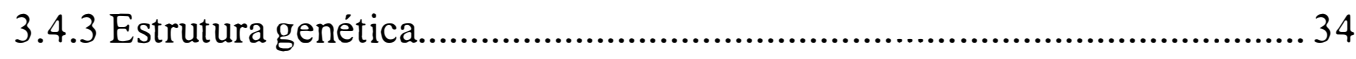

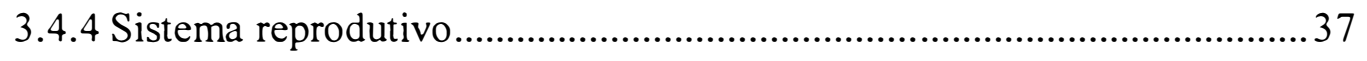

3.4.4.1 Equilíbrio de Hardy-Weinberg.................................................... 37

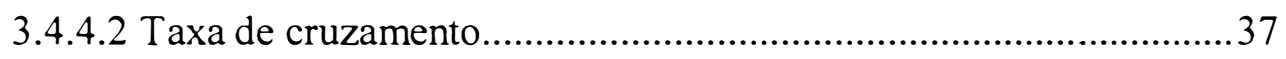

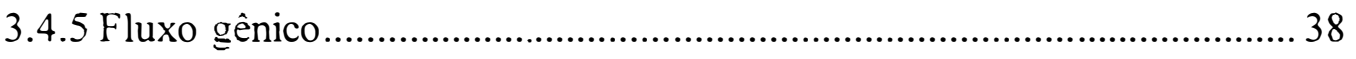

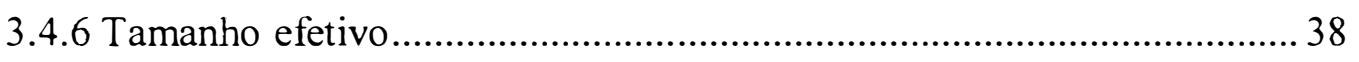




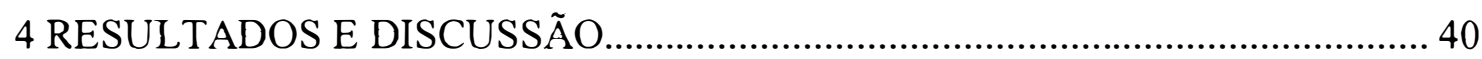

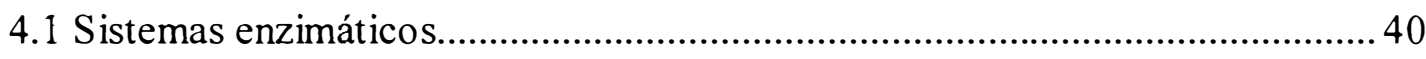

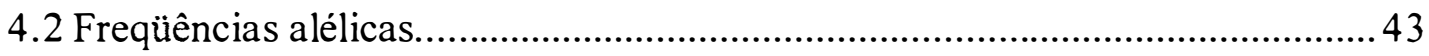

4.3 Variação genética intrapopulacional.............................................................. 45

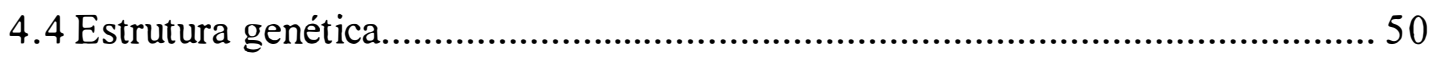

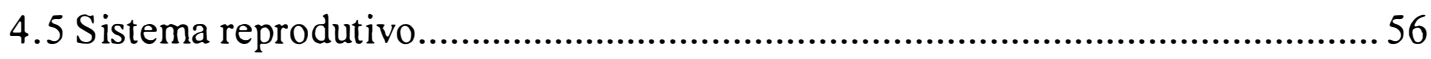

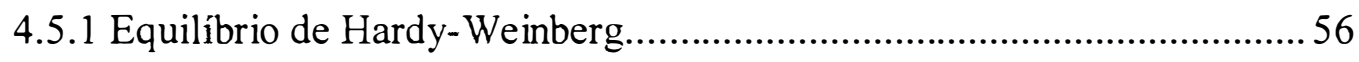

4.5.2 Taxas de cruzamento multilocos e unilocos.............................................58

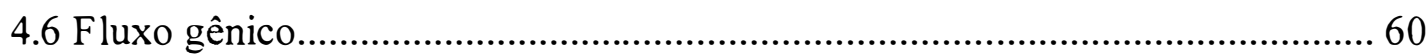

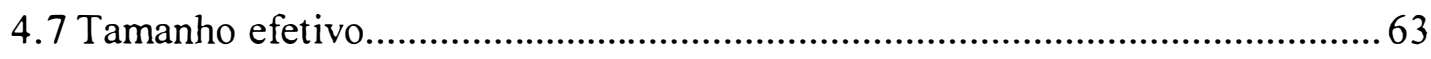

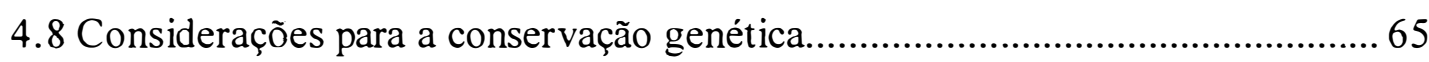

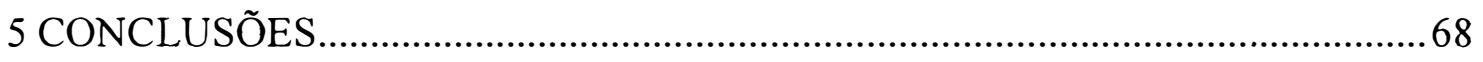

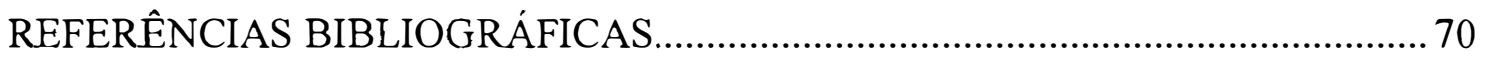




\title{
ESTRUTURA GENÉTICA DE POPULAÇÕES NATURAIS DE Syagrus romanzoffiana (ARECACEAE) DO CONTINENTE (SERRA DO MAR, S.P.) E DA ILHA DOS ALCATRAZES
}

\author{
Autora: MARTA ORGANO NEGRÃO \\ Orientador: Prof. Dr.PAULO YOSHIO KAGEYAMA
}

\section{RESUMO}

Este trabalho objetivou a caracterização isoenzimática de três populações naturais de Syagrus romanzoffiana (Chamisso) Glassman. uma situada na Ilha dos Alcatrazes, e as outras duas no continente, nos municípios de Bertioga e São Sebastião, SP. Foram tomados tecidos foliares de 5 progênies e de 30 indivíduos adultos de cada população para as análises de eletroforese de isoenzimas. sendo avaliados 8 sistemas enzimáticos para progênies (com um total de 15 alelos) e 2 para indivíduos adultos (total de 5 alelos). A espécie apresentou heterozigosidade esperada. número médio de alelos por loco e proporção de locos polimórficos $(0,99)$ respectivamente iguais a $0.140,1.59$ e 45.83. para progênies. e 0.342. 2.33 e 83.33, para indivíduos adultos.

Os resultados mostraram índices de diversidade genética para a espécie dentro dos padrões geralmente obtidos para espécies arbóreas tropicais. Todas as populações estudadas revelaram níveis similares de variação genética intrapopulacional. com exceção da proporção de locos polimórficos, que apresentou-se um pouco inferior para a população de São Sebastião. Foi encontrada, porém, grande divergência genética entre as populações $\left(\hat{\theta}_{\mathrm{p}}=0.259\right)$. mostrando a população de São Sebastião grande divergência das outras duas populações. mas a população da Ilha dos Alcatrazes pouca divergência genética da de Bertioga. Estes resultados sugerem que as populações da Ilha dos Alcatrazes e de Bertioga tenham surgido a partir de uma base genética comum. uma vez que o fluxo gênico é pouco provável. 
Para dados de progênies, a população de Alcatrazes e de São Sebastião mostraram tamanhos efetivos maiores que a população de Bertioga, o que parece ser devido à ocorrência de cruzamentos biparentais nesta última população. Já para dados de adultos, as populações de Alcatrazes e Bertioga tiveram tamanhos efetivos semelhantes aos números de indivíduos amostrados, enquanto que a população de Bertioga apresentou um tamanho efetivo inferior.

A grande maioria dos locos encontram-se em equilibrio de Hardy-Weinberg, sugerindo o acasalamento aleatório. A taxa de cruzamento multilocos média foi alta $\left(\hat{t}_{m}=0.918\right)$, mostrando-se a espécie preferencialmente alógama. Há uma tendência de não haver cruzamento entre indivíduos aparentados.

A deriva genética ficou evidenciada a partir da alta divergência interpopulacional e pequeno endocruzamento dentro das populações, da distribuição aleatória dos alelos (alelos exclusivos, fixação e perda de alelos, diferenças de freqüências gênicas entre populações), e do fluxo gênico aparente ( $\hat{\mathrm{N} m}$ ) menor do que 1.

Como grande parte da variação genética se encontra entre as populações, é importante considerar-se grande número de populações para a conservação genética da espécie. A coleta de germoplasma deve seguir este mesmo critério, adotando-se um maior esforço amostral em relação às populações do que em relação a indivíduos dentro de populações.

A população de Syagrus romanzoffiana da Ilha dos Alcatrazes possui uma relativamente alta variação genética. tamanho populacional grande (ordem de milhar). alta densidade populacional e alelos exclusivos. sendo dotada de uma combinação singular de características que lhe confere um valor único para a conservação genética. 
GENETIC STRUCTURE OF NATURAL POPULATIONS OF Syagrus romanzoffiana (ARECACEAE) IN THE CONTINENT (ATLANTIC COAST, STATE OF SAO PAULO) AND THE ALCATRAZES ISLAND

\author{
Author: MARTA ORGANO NEGRÃO \\ Adviser: Prof. PAULO YOSHIO KAGEYAMA
}

\title{
SUMMARY
}

The objective of this work was to isozymatically characterize three natural populations of Syagrus romanzoffiana (Chamisso) Glassman: one from Alcatrazes Island and two other mainland populations from Bertioga and São Sebastião municipalities in the state of São Paulo. Leaf tissue was taken from 5 of the 30 adult individuals in each population for isozyme electrophoresis analysis. Eight enzymatic systems were evaluated in progenies ( 15 alleles total) and two in adults ( 5 alleles total). Expected heterozygosity, average number of alleles per locus and proportion of polymorphic loci (0.99) for the specie were respectively 0.140. 1.59 and 45.83 for progenies and 0.342. 2.33 and 83.33 for adults.

Genetic diversity indices for the species were within those generally found for tropical woody species. All the populations studied revealed similar levels of intrapopulational genetic variation with the exception of the proportion of polymorphic loci. which was slightly lower in the São Sebastião population. However. a large genetic divergence among the populations was found $\left(\hat{\theta}_{P}=0.259\right)$. indicating the São Sebastião population to be greatly different from the other two populations. Furthermore, the Alcatrazes Island population showed little genetic divergence from the Bertioga one. These results suggest that populations from Alcatrazes 1sland and Bertioga originated from a common genetic base since gene flow is very unlikely. 
Progenies from Alcatrazes and São Sebastião populations had larger effective sizes than the Bertioga population, which may be due to the occurrence of biparental mating in the latter population. On the other hand, adult individuals from the Alcatrazes and Bertioga populations had effective sizes similar to the actual sizes (sample census number), while the effective size of the Bertioga population was smaller than the actual size.

Most of the loci were in Hardy-Weinberg equilibrium, which suggests random mating. The average multilocus outcrossing rate was high $\left(\hat{t}_{m}=0.918\right)$, indicating that the specie is preferentially allogamous. Mating among related individuals is unlikely.

Genetic drift was demonstrated by high interpopulational divergence as well as small inbreeding within populations, random allele distribution (exclusive alleles, fixation and allele loss, different gene frequencies among populations) and an apparent genetic flow ( $\hat{\mathrm{N} m}$ ) less than 1 .

Since much genetic variation is found among the populations, it is important to consider a large number of populations for genetic conservation of the species. Germplasm collection should follow the same criterion. adopting a greater sampling effort regarding populations than the individuals within the populations.

The Syagrus romanzoffiana population from Alcatrazes Island has relatively high genetic variation. large population size (in the thousands). high population density and exclusive alleles. forming a singular combination of characteristics that make it uniquely valuable for genetic conservation. 


\section{INTRODUÇÃO}

O entendimento da distribuição da variação genética em populações naturais de espécies arbóreas é fundamental para a compreensão da floresta tropical e conseqüente efetuação de propostas de manejo e conservação, especialmente quando se considera a conservação a longo prazo. Vários estudos visando a quantificação da variação genética em populações naturais de espécies arbóreas tropicais têm sido realizados recentemente. Entretanto, são poucos os estudos realizados com espécies da Mata Atlântica, que apresenta altas taxas de diversidade e endemismo e grande destruição da floresta. Os ecossistemas insulares exigem grande conhecimento que direcione a sua conservação, já que sujeitos ao isolamento e tamanho limitado, tornam-se frágeis frente à degradação antropomórfica. Estudos de genética de populações são de grande valia na caracterização de populações de espécies que habitam as ilhas e na verificação do contraste existente com populações continentais, conferindo assim uma visão mais abrangente de sua importância para a conservação.

As ilhas são objetos de estudo fascinantes pois guardam em si o registro da ação de um longo período de tempo. Funcionam como um laboratório natural, possuindo uma população colonizadora que permaneceu isolada de outras populações por um grande período. As ilhas são importantes para estudos evolutivos que buscam o entendimento do comportamento dos genes em populações pequenas e com fluxo gênico restrito. São situações extremas que podem ser úteis no entendimento de populações que sofreram grande redução de tamanho e posterior isolamento, como ocorre em várias espécies devido à intervenção humana nos diversos ecossistemas. As populações pequenas e/ou isoladas estão mais sujeitas a efeitos de deriva genética. sendo estes muitas vezes sugeridos como fatores determinantes de sua estrutura genética. 
Este trabalho tem como objetivo a caracterização isoenzimática de três populações naturais de Syagrus romanzoffiana, uma situada na Ilha dos Alcatrazes e duas no continente, em Bertioga e São Sebastião (municipios litorâneos do Estado de São Paulo). Foram estimadas as freqüências alélicas e niveis de diversidade genética, bem como foi analisada a estrutura genética populacional, a fim de observar a distribuição da variação genética e verificar se existem contrastes entre a população da Ilha e as populações continentais.

A caracterização genética permite também a avaliação da importância da população de S. romanzoffiana da Ilha dos Alcatrazes em relação a outras populações. A espécie apresenta na Ilha uma notável expressão em número de indivíduos e densidade populacional, sendo em alguns pontos a espécie predominante. A Ilha dos Alcatrazes vem sendo bombardeada pela Marinha do Brasil, que a utiliza como alvo para treinamento militar, apesar de ser o maior sítio de reprodução de aves marinhas do sudeste brasileiro, possuir uma das maiores concentrações de endemismo do Brasil e espécies ameaçadas de extinção. 


\section{REVISÃO DE LITERATURA}

\subsection{O Jerivá}

A América é, por assim dizer, o reino dos Cocosoideae, possuindo uma flora palmítica das mais variadas, sendo o jerivá (Syagrus romanzoffiana Chamisso Glassman) uma das Cocosoideae não espinhosas mais importantes (ALVES e DEMATTÊ, 1987). O jerivá pertence à família Arecaceae, e à sub-família Cocosoideae. O gênero Syagrus passou por várias mudanças de classificação, com sinonímias com os gêneros Cocos, Glaziova e Arecastrum.

A área de ocorrência do Syagrus romanzoffiana abrange os Estados do Espírito Santo, Rio de Janeiro, São Paulo, Minas Gerais, Bahia, Goiás, Mato Grosso do Sul até o Rio Grande do Sul, em quase todas as formações vegetais, sendo também encontrado no Paraguai, Argentina e Uruguai (LORENZI, 1992; ALVES e DEMATTÊ, 1987). É uma palmeira comum na região dos campos e savanas, matas ciliares do planalto brasileiro e nas regiões serranas dos sertões (ALVES e DEMATTÊ, 1987). O jerivá é particularmente abundante nos agrupamentos vegetais primários localizados em solos muito úmidos, brejosos ou particularmente inundáveis (REITZ, 1974, LORENZI, 1992). É raro na mata primária da encosta Atlântica e descontínuo nas matas de altitude, sendo mais freqüentemente encontrado nas capoeiras e áreas recém abandonadas (LORENZI, 1992), encontrando-se nestes locais intensa regeneração (REITZ, 1974). COIMBRAFILHO (1976) encontrou o jerivá em matas remanescentes no extremo oeste do Estado de São Paulo, citando a espécie como resistente ao fogo rasteiro e abundante em locais que sofreram derrubadas e queimadas. 
Como a maioria das palmeiras, o jerivá é uma planta monóica, possuindo flores masculinas e femininas no mesmo cacho (ALVES e DEMATTÊ, 1987). É uma planta de estipe alto, anelado, alcançando cerca de 15 metros de altura e $20 \mathrm{~cm}$ de diâmetro. Seus frutos são drupas elípticas de $3 \mathrm{~cm}$ de comprimento, fibrosas, mucilagenosas e de cor alaranjada. O estipe e os frutos apresentam polimorfismo de acordo com o clima, solo e altitude (BARBOSA RODRIGUES, 1903, citado por MAIA et al., 1987). As variações morfológicas desta espécie em função de sua região de ocorrência são também citadas por LORENZI (1992). REITZ (1974) indica a existência de duas variedades, em função do formato e tamanho do fruto apresentado. O jerivá floresce quase o ano inteiro, entretanto com maior intensidade a partir de setembro até março; a maturação dos frutos ocorre predominantemente de fevereiro a agosto (LORENZI, 1992).

O jerivá é também conhecido por coqueiro (SC), coco-de-cachorro(SC), baba-deboi (RJ), gerivá e coqueiro-gerivá (LORENZI, 1992; REITZ, 1974). O nome indígena jerivá vem de "yarivá" que por sua vez procede de "yarib" e "uá", frutos que dão em espádices ou, segundo outros, de "yary", gomoso, e "ya", fruto, portanto "yariyuá" significa fruta gomosa; exatamente por isso é chamado de baba-de-boi no Rio de Janeiro (REITZ, 1974). Em Santa Catarina essa palmeira também é conhecida por coco-decachorro porque os cães selvagens (graxaim) apreciam muito seus frutos sendo freqüentemente encontrados no mato os monturos fecais quase unicamente de cocos despolpados pela digestão (REITZ, 1974).

A dispersão de sementes do jerivá é também efetuada por outros animais. O esquilo caxinguelê (Sciurus ingrami) é citado ser um dispersor e predador dos frutos do jerivá (MAIA et al., 1987; PASCHOAL e GALETTI, 1995), que podem constituir quase $40 \%$ de sua dieta. Os esquilos usualmente predam as sementes, porém foram vistos pegando frutos de $S$. romanzoffiana em buracos que eles cavam no solo (PASCHOAL e GALETTI, 1995), podendo assim atuar como dispersores. Os frutos do jerivá são consumidos também pelo mico leão preto (Leontopithecus chrysopygus), que come o exocarpo dos frutos, podendo compreender mais de $79 \%$ da parte vegetal de sua alimentação (MAMEDE-COSTA e GODOI, 1998). Estes autores ressaltam a importância dos frutos do jerivá para o mico leão, uma vez que constitui um componente 
significativo de sua dieta durante nove meses no ano e recurso chave para a sua sobrevivência nos poucos e pequenos fragmentos florestais nos quais ele existe hoje. Outros primatas como o macaco-prego (Cebus apella) e o bugio (Alouatta fusca) se alimentam dos frutos do S. romanzoffiana, que constituem, respectivamente, cerca de $2.2 \%$ e $0,25 \%$ das dietas desses animais (GALETTI et al., 1987, citado por MAMEDECOSTA e GODOI, 1998). Os frutos do jerivá podem também fazer parte da alimentação de aves, dispersoras potenciais desta palmeira. O sabiá-laranjeira (Turdus rufiventris) foi observado se alimentando regularmente de frutos do jerivá, e tucanos (Ramphastos dicolorus) também se alimentaram dos frutos da palmeira, porém somente ocasionalmente, sendo que em ambas espécies os frutos foram ingeridos, a polpa removida e as sementes regurgitadas (GUIX e RUIZ, 1995). Duas espécies de Penelope, P. obscura (jacuaçu) e P. superciliaris (jacupemba ou jacutinga) foram observadas se alimentando dos frutos do jerivá, retirando os frutos diretamente dos cachos e defecando sementes inteiras após a digestão (GUIX e RUIZ, 1997).

A madeira do jerivá é empregada localmente no preparo de estivados sobre solos brejosos, pinguelas e trapiches de água salgada (LORENZI, 1992). A planta é altamente decorativa, e aliada à grande facilidade de transplante quando adulta, transformou-se na palmeira mais empregada na arborização de ruas e avenidas de todo o país. Ainda segundo o mesmo autor, os frutos são avidamente procurados por várias espécies de animais, o que torna o jerivá recomendável para o plantio em agrupamentos mistos de áreas degradadas e de preservação permanente. 


\subsection{Considerações gerais sobre as palmeiras}

As palmeiras tipificam os trópicos; elas constituem uma linhagem antiga, e variam de espécies comuns dispersas amplamente a endêmicas raras altamente restritas em paisagens fragmentadas (TOMLINSON, 1979). Segundo o autor, elas parecem estar restritas a ambientes tropicais e subtropicais principalmente porque o crescimento vegetativo é essencialmente contínuo e elas não possuem mecanismos de dormência. $75 \%$ das palmeiras são espécies tropicais, mas sua grande diversidade de hábitos no subbosque sugere uma apreciável diversidade de papéis ambientais (DRANSFIELD, 1978, citado por TOMLINSON, 1979). Apesar desta forte predileção por habitats úmidos e clima tropical (TOMLINSON, 1979), há espécies típicas dos desertos, de montanhas, ou de clima frio ou temperado (ALVES e DEMATTÊ, 1987). Algumas delas mostram-se especialmente características de ambientes perturbados; em locais abertos as palmeiras tentam compensar a falta de espécies por um grande número de indivíduos (TOMLINSON, 1979).

A família Arecaceae (=Palmae) é a única contida na ordem Arecales. As Arecaceae são, entre as Liliopsida (=Monocotyledoneae), um grupo à parte, com caracteres morfológicos e anatômicos que podem distingui-las de qualquer outro vegetal (ALVES e DEMATTÊ, 1987). A família caracteriza-se pelo pistilo com três carpelos, em regra com um óvulo por carpelo, flores com perigônio verdadeiro, inflorescência envolta por espatas, plantas em geral terrestres, arborescentes (BONDAR, 1964, citado por ALVES e DEMATTÊ, 1987). Apesar da anemofilia ocorrer em palmeiras, mecanismos de polinização por animais não só são freqüentes, mas diversos (TOMLINSON, 1979). O monoicismo é a condição mais comum na fámília, mas a distribuição de flores masculinas e femininas é variável.

As palmeiras estão entre as primeiras famílias de Angiospermae e as primeiras Magnoliophyta de que se tem registro na história natural (ALVES e DEMATTÊ, 1987). As Cocosoideae são um grupo à parte. Quase todos os gêneros são da América tropical, com exceção de Elaeis e Jubaeopsis, com espécies africanas, e Cocos, que se distribui por todo o mundo. A simultaneidade do aparecimento das palmeiras e o processo de 
divisão dos continentes deram uma configuração muito especial na sua distribuição geográfica, pois as floras são bem diferenciadas nos continentes. É possível que, quando surgiram as primeiras Cocosoideae, os continentes americano e africano estivessem bem próximos, e depois de sua separação final, essas floras se desenvolveram, com as Cocosoideae dominando a América e as Borassoideae, a África e o arquipélago Malgaxe (ALVES e DEMATTÊ, 1987). O número de cromossomos nas palmeiras varia de 13 a 18 , sendo evidente a tendência de evolução do número básico de $\mathrm{n}=18$, nas mais primitivas e na maioria dos gêneros de Coryphoidae, para 13 a 17 nos grupos mais evoluídos (MOORE e UHL, 1982, citados por ALVES e DEMATTÊ, 1987).

A genética de populações de palmeiras tem sido muito pouco estudada (EGUIARTE et al., 1992; LOPES et al., 1992; DOWE et al., 1997). Alguns poucos estudos têm sido realizados com isoenzimas.

Dentre os estudos realizados, pode-se citar o de REIS (1996) com o palmiteiro (Euterpe edulis), uma palmeira de sub-bosque da Floresta Pluvial Atlântica brasileira. A espécie apresentou uma heterozigosidade esperada alta tanto para adultos quanto para progênies; os resultados indicaram também menor divergência entre populações contíguas, uma alta taxa de cruzamento multilocos e alto fluxo gênico. A macaúba (Acrocomia aculeata), uma palmeira que ocorre por todo o Brasil, foi estudada por LOPES et al (1992). Foi encontrada uma alta diversidade genética e muitos locos polimórficos. Segundo os autores, o alto nível de variação genética não é surpreendente por causa da alta taxa de cruzamento na espécie, em torno de $85 \%$. Astrocaryum mexicanum, uma palmeira tropical do sub-bosque que ocorre no México, apresentou níveis relativamente altos de variação genética, alta taxa de cruzamento multilocos e baixa diferenciação genética entre populações (EGUIARTE et al., 1992), que segundo os autores, parece ser comum em espécies arbóreas tropicais.

McCLENAGHAN e BEAUCHAMP (1986) estudaram a palmeira Washingtonia filifera, uma espécie endêmica do sudoeste do E.U.A. e norte de Baja California, México. A espécie apresentou baixos níveis de variabilidade genética intra e interpopulacional. Ptychosperma bleeseri, uma palmeira rara de sub-dossel, é conhecida em apenas oito remanescentes de floresta na Austrália, possuindo muito poucos indivíduos 
por população. A análise isoenzimática mostrou que quase não há variação genética; das 223 amostras testadas, somente 4 indivíduos variaram em um único loco dos 10 locos analisados (SHAPCOTT, 1998).

A tabela 1 mostra dados de variação genética e taxa de cruzamento de espécies de palmeiras. Pode-se observar que a taxa de cruzamento apresenta valores altos. Os valores de diversidade variam expansivamente, desde valores muito baixos até muito elevados. Porém, os valores muito baixos correspondem às espécies de distribuição muito restrita (Washingtonia filifera e Ptychosperma bleeseri). Para o restante das espécies, os valores de porcentagem de locos polimórficos. número de alelos por loco e heterozigosidade esperada ou são bastante altos, ou medianos (Astrocaryum mexicanum).

Tabela 1: Valores de variação genética e taxa de cruzamento de palmeiras estudadas por isoenzimas

\begin{tabular}{|c|c|c|c|c|c|}
\hline Palmeira & A & $\mathrm{P}$ & $\mathrm{H}_{\mathrm{e}}$ & $t_{m}$ & Fonte \\
\hline Astrocaryum mexicanum & 1,36 & 31,8 & 0,153 & 0,99 & EGUIARTE et al. (1992) \\
\hline Acrocomia aculeata ${ }^{\mathrm{a} b}$ & 2,00 & 100,0 & 0,375 & 0,85 & LOPES et al. (1992) \\
\hline Euterpe edulis ${ }^{\mathrm{b}}$ & 3,40 & - & 0,452 & 0,99 & REIS (1996) \\
\hline Washingtonia filifera & 1,75 & 9,8 & 0,008 & & McCLENAGHAN e BEAUCHAMP (1986) \\
\hline Ptychosperma bleeseri & 1,03 & 2,9 & 0,007 & & SHAPCOTT (1998) \\
\hline Phoenix dactylifera & 2,28 & 100,0 & 0,436 & & BENNACER et al. $(1991)^{\mathrm{C}}$ \\
\hline média & $1,61^{d}$ & $36,13^{d}$ & $0,151^{\mathrm{d}}$ & 0,94 & \\
\hline média não endêmicas & $1,82^{d}$ & $65,90^{d}$ & $0,294^{d}$ & 0,94 & \\
\hline média arbóreas tropicais & 1,90 & 47,4 & 0,178 & & $\operatorname{MORAES}(1997)^{\mathrm{e}}$ \\
\hline
\end{tabular}

$\mathrm{A}=$ número médio de alelos por loco, $\mathrm{P}=$ porcentagem de locos polimórficos média, $\mathrm{H}_{\mathrm{e}}=$ heterozigosidade esperada média, $\mathrm{t}_{\mathrm{m}}=$ taxa de cruzamento multilocos. ${ }^{\mathrm{a}}$ dados de progênies; ${ }^{\mathrm{b}}$ considerando apenas locos polimórficos; 'citado por Reis (1996); ' exceto Euterpe edulis (considera apenas locos polimórficos) e Acrocomia aculeata (considera dados de progênies); ${ }^{\mathrm{e}}$ cálculo de médias feito a partir de tabela apresentada pelo autor. 


\subsection{Estrutura genética e sistema reprodutivo de espécies arbóreas tropicais}

Tem sido demonstrado que a variação genética em populações de plantas é distribuída de forma não-aleatória (HAMRICK, 1990), sendo que este tipo de distribuição é freqüentemente referido como estrutura genética de uma população (LOVELESS e HAMRICK, 1984). Em outras palavras, a estrutura genética se constitui na distribuição da variação genética entre e dentro de populações (BROWN, 1978). De uma forma geral, a estrutura genética de populações de plantas é o resultado de um balanço de forças que tendem a produzir diferenciação genética (seleção natural, deriva genética e mutação) e forças que tendem a produzir homogeneização genética (fluxo gênico). Neste contexto, diversos fatores ecológicos e evolutivos influenciam a estrutura genética, como tamanho efetivo populacional, sistema de cruzamento, dispersão de pólen e sementes, fenologia, densidade populacional, amplitude geográfica, entre outros (LOVELESS e HAMRICK, 1984; HAMRICK, 1990).

Conforme HAMRICK (1990), revisões recentes indicam que plantas geralmente mantêm níveis relativamente altos de variação aloenzimática dentro de populações. Há também uma considerável heterogeneidade para níveis de variação interpopulacional entre diferentes espécies, estando eles relacionados com a história vital e com as características ecológicas das espécies (HAMRICK et al., 1979). HAMRICK e GODT (1990), em uma revisão de literatura de aloenzimas de plantas, observaram que, em média, as plantas apresentaram 50,5\% de locos polimórficos, número de alelos por loco igual a 1,96 e heterozigosidade esperada média de 0,149. Ao nível populacional, a distribuição geográfica e o sistema de cruzamento são os fatores que estão mais associados aos parâmetros genéticos de diversidade. A variação genética entre populações foi influenciada principalmente pelo sistema de cruzamento. O potencial de fluxo gênico teve a influência predominante na repartição da variação alozímica entre populações. Os autores confirmam as generalizações estabelecidas em revisões anteriores (HAMRICK et al., 1979; BROWN, 1979; GOTTLIEB, 1981; LOVELESS e HAMRICK, 1984, citados por HAMRICK e GODT, 1990), que espécies alógamas, polinizadas por vento, perenes e dos estágios finais de sucessão possuem os maiores 
níveis de variação aloenzimática dentro das populações e menores entre populações do que espécies com outras combinações de características. Segundo GEBUREK (1997), nas espécies arbóreas, 5-10\% da variação alozímica, em média, é devido à variação interpopulacional, e $90-95 \%$ da variação reside dentro de populações. Já para plantas arbóreas tropicais, BAWA (1992) indica que há diversidade genética considerável dentro de populações e que a diferenciação genética entre populações é alta em algumas espécies e baixa em outras.

HAMRICK e GODT (1990) encontraram que as espécies tropicais não apresentam diferenças em heterozigosidade $\left(\mathrm{H}_{\mathrm{e}}\right)$ e proporção de locos polimórficos $(\mathrm{P})$ em relação às espécies temperadas, e possuem valores menores que as boreais. Apesar disso, conforme a tabela a seguir, as árvores tropicais podem apresentar um valor de $\mathrm{H}_{e}$ um pouco superior do das espécies tropicais em geral e do médio das plantas (tabela 2). Os valores de $\mathrm{A}$ e $\mathrm{P}$, porém, não mostram os mesmos resultados.

Tabela 2: Índices de diversidade para diferentes grupos de plantas.

\begin{tabular}{lccccl}
\hline \hline \multicolumn{1}{c}{ Grupo } & $\mathbf{N}^{\mathbf{0}} \mathbf{d e ~ t a x a}$ & $\mathbf{A}$ & $\mathbf{P}$ & $\mathbf{H}_{\mathbf{e}}$ & \multicolumn{1}{c}{ Fonte } \\
\hline plantas (média geral) & 473 & 1,96 & 50,5 & 0,149 & HAMRICK e GODT, 1990 \\
arbóreas tropicais & $63 ; 88 ; 98^{\mathrm{a}}$ & 1,90 & 47,4 & 0,178 & MORAES, 1997 \\
espécies tropicais & 76 & 1,81 & 49,2 & 0.148 & HAMRICK e GODT, 1990 \\
gimnospermas & 55 & 2,35 & 70,9 & 0.173 & HAMRICK e GODT, 1990 \\
dicotiledôneas & 329 & 1,79 & 44,8 & 0,136 & HAMRICK e GODT, 1990 \\
monocotiledôneas & 111 & 2,38 & 59,2 & 0,181 & HAMRICK e GODT, 1990 \\
\hline \hline
\end{tabular}

A: $^{\mathbf{0}}$ médio de alelos por loco; P:porcentagem de locos polimórficos; $\mathrm{H}_{\mathrm{e}}$ : Heterozigosidade média esperada

${ }^{a}$ Para $\mathrm{A}, \mathrm{Pe} \mathrm{H}_{e}$, respectivamente. ${ }^{\mathrm{b}} \mathrm{Cá} l \mathrm{l} u l o$ de médias feito a partir de tabela apresentada pelo autor.

Os sistemas de cruzamento determinam o modo de transmissão de genes de uma geração à outra (BROWN,1990). Um ponto crucial na dinâmica de populações de plantas é a geração de novos indivíduos para o futuro a partir dos existentes hoje (BROWN,1990), e assim, os sistemas de cruzamento determinam grandemente o número e a constituição genética da progênie que formam a matéria-prima para seleção 
futura. A relação genética entre progênies, heterogeneidade genética espacial dentro de populações e os níveis e distribuição da diversidade genética entre e dentro de populações são parâmetros que são diretamente afetados pelo sistema de cruzamento (HAMRICK e MURAWSKI, 1990).

Conforme cita BAWA (1992), estudos baseados na morfologia floral e polinizações controladas indicam a ocorrência da polinização cruzada, mas não fornecem informação sobre o nível de cruzamento que está ocorrendo. A taxa de cruzamento pode ser quantificada através da utilização de marcadores genéticos (BAWA, 1992), em delineamentos com progênies, medindo-se o impacto genético dos sistemas de cruzamento em termos de modelos (p. ex. sistema misto, sistema aleatório)(BROWN,1990).

As plantas exibem uma grande variedade de sistemas de cruzamento (BROWN,1990). Como é realçado por alguns autores, o sistema de cruzamento de plantas deveria ser pensado como um contínuo de possibilidades ao invés de tipos estritos. Contudo, é útil falar nos principais modos de cruzamento, porque as maiores conseqüências e abordagens diferem entre eles. Pode-se dividir convenientemente as espécies de plantas em cinco classes de cruzamento: predominantemente autógamas, predominantemente alógamas, de cruzamento misto (fertilização cruzada e autocruzamento), parcialmente apomíticas, e haplóides de autocruzamento parcial (BROWN,1990). Em florestas tropicais, as três classes intermediárias citadas tornam-se mais importantes.

BAWA (1992) ressalta que a pesquisa durante os últimos vinte anos tem mostrado que a maioria das espécies arbóreas tropicais são fortemente alógamas, possuindo altas taxas de cruzamento, e que a vasta maioria destas espécies são alógamas em virtude de serem auto-incompatíveis ou dióicas. Conforme o autor, há uma crescente evidência em espécies arbóreas tropicais para altas taxas de fluxo gênico e baixos níveis de diferenciação genética entre populações. 
A alogamia encontrada nas espécies arbóreas tropicais está em geral ligada à polinização por animais (BAWA, 1974; BAWA et al., 1985). Os diferentes padrões de distância de vôo dos polinizadores encontram-se associados a diferentes padrões de variabilidade genética nas populações de espécies arbóreas tropicais (KAGEYAMA e CASTRO, 1989). Assim, o tipo de distribuição espacial dos indivíduos de uma espécie poderia ser resultante do tipo de polinização e dispersão de sementes realizadas, visando a atender a especificidade do polinizador e dispersor (KAGEYAMA, 1990). Em vista disso, conforme o autor, poderia haver uma gradação nas espécies arbóreas, desde as com distribuição tipicamente agregada e distâncias curtas de pólen e sementes, até aquelas com distribuição muito dispersa e amplas distâncias de pólen e sementes, com implicações na sua estrutura genética.

Uma das metodologias empregadas para medição da variação genética em populações naturais é a técnica de eletroforese de aloenzimas. A introdução da técnica de eletroforese de aloenzimas nos estudos de genética de populações foi um marco muito importante, pois forneceu um meio direto de avaliação da variação genética (TORGGLER et al., 1995). Segundo os mesmos autores, mesmo havendo hoje técnicas suplementares que ampliam o poder de detecção dos efeitos de mutações ao nível de DNA, aloenzimas continuam ainda com um enorme potencial não totalmente explorado para aplicação em genética de plantas. $\mathrm{O}$ uso da informação genética expressa na forma de aloenzimas tem aumentado grandemente o conhecimento da estrutura genética de populações de plantas (KEPHART, 1990; HAMRICK e GODT, 1990). Os estudos com marcadores alozímicos têm feito importantes contribuições para a ecologia evolucionária, a genética de populações e a conservação dos recursos genéticos entre outros campos (HAMRICK e GODT 1990). É provável que marcadores moleculares robustos venham suplementar e não substituir as isoenzimas. Geralmente nenhum tipo de marcador de DNA resolve todos os problemas relacionados a marcadores para conservação genética de espécies arbóreas florestais. Desde que alguns tipos de marcadores de DNA são mais apropriados para a automação do que isoenzimas, a longo 
prazo eles poderão proporcionar maiores resultados (GEBUREK, 1997). Enquanto isso, as isoenzimas ainda dominam a detecção da variação genética em espécies arbóreas (GEBUREK, 1997).

A eletroforese de aloenzimas é uma técnica bioquímica que promove a separação de determinadas enzimas produzidas por um organismo. A eletroforese consiste na migração de moléculas ionizadas, de acordo com suas cargas elétricas e pesos moleculares, em um campo elétrico (ALFENAS et al.. 1991). Na eletroforese de aloenzimas, as moléculas empregadas são as enzimas, sendo elas separadas em função de sua variável composição de aminoácidos. A separação das enzimas em um meio suporte promove a visualização de uma série de bandas, que permite a genotipagem dos organismos para os respectivos locos enzimáticos. De posse dos genótipos dos indivíduos em estudo pode-se, então, obter as estimativas dos diversos parâmetros genéticos.

Embora os estudos eletroforéticos tenham sido muito utilizados para descrever a organização da variação genética em populações naturais de plantas, alguns grupos, incluindo espécies arbóreas tropicais, têm sido muito pouco estudados (GANDARA, 1996). Alguns estudos têm sido conduzidos em espécies arbóreas tropicais, principalmente na América Central (HAMRICK e LOVELESS, 1986; HAMRICK e MURAWSKI, 1991; EGUIARTE et al., 1992; PÉREZ-NASSER et al., 1993; HALL et al., 1994; e.g.), mas muito poucos na América do Sul, em especial na Floresta Atlântica (MORAES, 1992; SANTOS, 1994; REIS, 1996; GANDARA, 1996; e.g.).

A dinâmica das populações das espécies arbóreas. ou o entendimento de como um grupo de indivíduos numa população natural se perpetua no tempo e no espaço, é sem dúvida essencial para o manejo sustentado e para a conservação genética (KAGEYAMA e GANDARA, 1993). Segundo os mesmos autores, o conhecimento da variação genética entre e dentro das populações, assim como a variação no tempo, para que se possa abarcar toda a variação existente, é indispensável para a conservação genética de uma espécie. Ainda, para plantas longevas que tem que suportar alta heterogeneidade ambiental temporal e espacial, a diversidade genética é de principal importância para a persistência da espécie (GEBUREK, 1997) 
A conservação a longo prazo deve considerar a variação genética, já que esta se refere a um processo dinâmico, um processo de contínua evolução (FRANKEL e SOULÉ, 1981), e uma condição necessária para a evolução é um estoque de variação genética na população (CLEGG, 1990; SOLBRIG, 1980). A manutenção da variação genética, ou pelo menos sua quantificação, é um dos objetivos primários dos esforços em conservação (FALK e HOLSINGER, 1991), que promete ser um dos assuntos mais importantes da próxima década (GEBUREK, 1997).

\subsection{Efeitos genéticos em populações pequenas e/ou isoladas}

O tamanho pequeno de uma população pode trazer conseqüências genéticas específicas, de forma que ela seja afetada mais intensamente pela ação de forças evolutivas de caráter estocástico. O mesmo ocorre com populações que se encontram isoladas de demais populações. Muitas vezes esses dois fatores, isolamento e tamanho pequeno, são avaliados conjuntamente, uma vez que é relativamente freqüente a sua associação em populações naturais. As populações insulares são um exemplo característico.

A teoria genética de populações finitas simplesmente descreve na sua maioria o efeito do tamanho populacional e da migração na deriva genética e suas conseqüências na estrutura genética de populações. Os modelos geralmente assumem acasalamento aleatório e ausência de seleção ou mutação (BARRETT e HUSBAND, 1990).

A teoria prediz que populações pequenas geralmente mantém níveis menores de variabilidade genética intrapopulacional do que populações grandes (WRIGHT, 1931; NEI et al., 1975), sendo as populações menores mais susceptíveis à perda de variabilidade genética por deriva. A deriva genética é uma mudança na freqüência gênica devida inteiramente ao acaso. Este processo ocorre em toda população finita (i.e., em todas as populações), mas é tanto mais rápido quanto menor for a população (FUTUYMA, 1992). 
Estudos empíricos mostram uma tendência geral de populações maiores possuírem maior variação genética que populações menores. Porém, em uma revisão, ELLSTRAND e ELAM (1993) mostram que as medidas de variação genética mais freqüentemente correlacionadas com o tamanho de população são porcentagem de locos polimórficos $(\mathrm{P})$ e número de alelos por loco $(\mathrm{A})$. Em poucos casos, a diversidade gênica $\left(\mathrm{H}_{e}\right)$ está associada com o tamanho populacional. Quando o tamanho populacional e a variação covariaram, a variação entre populações tendeu a ser relativamente alta. Estes resultados podem ser observados na tabela a seguir.

Tabela 3: Sumário dos estudos associando tamanho populacional e variação genética em plantas.

\begin{tabular}{lll}
\hline Espécie & Associação positiva? & $\mathbf{G}_{\mathbf{S T}}$ \\
\hline Acacia anomala & Não & 0,06 \\
Eucalyptus caesia & $\operatorname{Sim}(\mathrm{P})$ & 0,61 \\
Eucalyptus crucis & $\operatorname{Sim}\left(\mathrm{P}, \mathrm{A}, \mathrm{H}_{\mathrm{e}}\right)$ & 0,24 \\
Eucalyptus parvifolia & $\mathrm{Não}$ & 0,07 \\
Eucalyptus pendens & $\mathrm{Não}$ & 0,08 \\
Eucalyptus pulverulenta & $\mathrm{Sim}\left(\mathrm{P}, \mathrm{A}, \mathrm{H}_{\mathrm{e}}\right)$ & 0,30 \\
Halocarpus bidwillii & $\mathrm{Sim}\left(\mathrm{P}, \mathrm{A}, \mathrm{H}_{\mathrm{e}}\right)$ & 0,04 \\
Salvia pratensis & $\mathrm{Sim}(\mathrm{P}, \mathrm{A})$ & 0,16 \\
Scabinosa columbaria & $\mathrm{Sim}(\mathrm{P}, \mathrm{A})$ & 0,18 \\
Washingtonia filifera & $\mathrm{Sim}(\mathrm{P})$ & 0,02 \\
\hline
\end{tabular}

P: porcentagem de locos polimórficos; $\mathrm{A}: \mathrm{n}^{\mathrm{O}}$ de alelos por loco; $\mathrm{H}_{\mathrm{e}}$ : diversidade gênica. Retirado de Ellstrand e Elam (1993)

Outros estudos com espécies arbóreas mostram resultados semelhantes. A heterozigosidade observada em Picea rubens foi menor em populações pequenas e isoladas do que em populações do restante da distribuição (HAWLEY e DeHAYES, 1994). QIU e PARKS (1994), estudando três espécies de Magnolia, encontraram que $M$. fraseri, com populações grandes e contínuas, tem níveis médios de variação ao nível populacional $\left(\mathrm{A}, \mathrm{P}, \mathrm{H}_{\mathrm{e}}\right.$ ) enquanto que $M$. macrophylla e $M$. tripetala, que ocorrem freqüentemente em populações pequenas e isoladas, possuem baixa variação. 
Populações pequenas e isoladas de Acacia mangium mostraram baixos níveis de diversidade $\left(\mathrm{H}_{\mathrm{e}}\right.$, através de RFLP), enquanto que as populações grandes tiveram níveis maiores de diversidade (BUTCHER et al., 1998).

Segundo FUTUYMA (1992), a deriva genética apresenta numerosas conseqüências evolutivas, duas da quais merecem ênfase especial: ela resulta na perda de variação genética dentro das populações e na divergência genética entre as populações. A variação total no entanto permanece igual. Os exemplos de trabalhos com espécies arbóreas, nos quais a deriva é colocada como agente responsável pela distribuição da variação genética entre e dentro de populações, são mais numerosos. Neles, os autores atribuem os altos niveis de variação interpopulacional e baixos niveis de variação intrapopulacional principalmente a efeitos de deriva, como em Eucalyptus pulverulenta (PETERS et al., 1990), Eucalyptus caesia (MORAN e HOPPER, 1983), e nas coniferas Cathaya argyrophylla (GE et al., 1998) e Agathis borneensis (KITAMURA e RAHMAN, 1992). Um nivel mais baixo de variação intrapopulacional foi encontrado em populações isoladas de Eucalyptus nitens (COOK e LADIGES, 1998), Melaleuca alternifolia (BUTCHER et al., 1992) e Pinus sylvestris (GONCHARENKO et al., 1994). SHERMAN-BOYLES et al. 1992., citados por BUTCHER et al., 1992, encontraram uma reduzida variação por loco, mas níveis de variação genética similares em populações mais isoladas de Ulmus crassifolia do que em populações da distribuição principal da espécie.

Um outro fator de considerável relevância para a estrutura genética de populações é o fluxo gênico. O fluxo gênico tem o efeito de homogeneizar a composição genética, de modo que se ele for o único fator operante, todas as populações irão convergir para uma mesma freqüência alélica (FUTUYMA, 1992). Conforme o mesmo autor, se os alelos forem seletivamente neutros, mas os tamanhos populacionais forem tão pequenos que a deriva genética se torna importante, a convergência das freqüências alélicas provocada pelo fluxo gênico será contrabalanceada pela divergência aleatória causada pela deriva genética. SLATKIN (1981) sugere que espécies com alto fluxo gênico desenvolvem-se como uma única unidade panmítica, enquanto que a seleção e a deriva podem ser bastante importantes em espécies que apresentem baixo fluxo gênico. 
O fluxo gênico, porém, deve exceder um determinado nível para evitar substancial diferenciação genética devida à deriva (WRIGHT, 1931). Segundo o autor, populações locais irão divergir por deriva se $\mathrm{Nm}$ (número de migrantes por geração) de uma população fonte for menor do que 1 , mas não se for maior do que 1 .

É esperado que populações isoladas estejam sujeitas a uma menor troca gênica com outras populações, apresentando assim uma maior divergência interpopulacional, como nos vários trabalhos anteriormente citados. Porém. nem sempre este padrão é encontrado na natureza; muitos estudos não encontram alta diferenciação genética entre populações isoladas. Em Pinus nigra as freqüências alélicas em 5 populações geograficamente relacionadas não tiveram nenhuma diferença das freqüências de 3 populações isoladas e o nível de diferenciação genética foi baixo, sendo aparentemente o resultado de fluxo gênico intenso (SILIN e GONCHARENKO, 1996). Outros estudos com espécies arbóreas também sugerem a atuação do fluxo gênico como força homogeneizadora, como os realizados com as espécies Melaleuca alternifolia (BUTCHER et al., 1992), Eucalyptus urophylla (HOUSE e BELL, 1994), Pinus strobus (RAJORA et alii, 1998) e Pinus sylvestris (GONCHARENKO et al., 1994).

O gargalo de garrafa é uma severa porém temporária restrição do tamanho populacional (MARUYAMA e FUERST, 1984). Quando o tamanho populacional é subitamente reduzido, a heterozigosidade média por loco é esperada decair, sendo que a taxa de declínio depende do tamanho efetivo populacional, enquanto que se o tamanho da população aumenta, a heterozigosidade média é esperada a aumentar devido a novas mutações (NEI et al, 1975).

Muitos estudos atribuem os níveis baixos de variação genética a gargalos que ocorreram durante o estabelecimento das populações atuais. MORAN et al. (1989) atribuíram os níveis extremamente baixos de diversidade genética em Acacia mangium a um gargalo devido à extinção de muitas populações durante as glaciações do Quaternário. Uma nova origem por um evento de hibridização também explicaria os resultados. Estudos em um pomar de sementes de Thuja plicata mostrou que esta espécie possui taxa de cruzamento e heterozigosidade muito baixas (EL-KASSABY et al., 1994). Segundo os autores, registros paleobotânicos indicam que esta espécie 
experenciou um gargalo severo entre 6000 a 10000 anos atrás, que pode ter sido responsável por estes baixos níveis de heterozigosidade. Outros trabalhos com espécies arbóreas que assumem a importância de gargalos na distribuição da variação genética são os realizados com Cathaya argyrophylla (GE et al., 1998), Acacia mangium (BUTCHER et al., 1998), e Magnolia macrophylla e Magnolia tripetala (QIU e PARKS, 1994).

NEI e colaboradores (1975) estudaram matematicamente o efeito de gargalo de garrafa, e os resultados indicaram que a redução na heterozigosidade média por loco depende não apenas da magnitude do gargalo, mas também da taxa de crescimento populacional. Se o tamanho da população aumenta rapidamente depois de passar pelo gargalo, a redução na heterozigosidade média é consideravelmente pequena ainda que o tamanho do gargalo seja estreito. Por outro lado, os autores concluem que a perda no número médio de alelos por loco é profundamente afetada pelo tamanho do gargalo mas não muito pela taxa de crescimento populacional. Esta diferença ocorre principalmente porque a deriva genética elimina muitos alelos de freqüência baixa, mas são os alelos de freqüência intermediária que contribuem consideravelmente para a heterozigosidade. Contudo, o número médio de alelos por loco aumenta mais rápido do que a heterozigosidade média quando o tamanho populacional é restaurado.

McCLENAGHAN e BEAUCHAMP (1986) observaram que o tamanho da população não correlacionou com a heterozigosidade, mas sim com a proporção de locos polimórficos na palmeira Washingtonia filifera, sugerindo então que talvez a proporção de locos polimórficos reflita mais claramente a influência de gargalos e mudanças no tamanho populacional. A perda de alelos de baixa freqüência durante a passagem pelo gargalo reduziria a proporção de locos polimórficos, porém, a proporção de heterozigotos será influenciada não somente por mudanças aleatórias nas freqüências alélicas, mas também por fatores como seleção natural e endocruzamento, cujos efeitos podem ser independentes do tamanho populacional. 
LEDIG et alii (1999) estudaram um pinheiro endêmico do México (Pinus maximartinezii) e encontraram que nenhum loco polimórfico tinha mais que dois alelos por loco e que a maioria dos alelos nos locos polimórficos possuíam freqüências intermediárias, resultado muito contrastante em relação a outros Pinus. Conforme os autores, uma população com somente dois alelos por loco em freqüências intermediárias poderia ocorrer se a população tivesse sido reduzida através de um gargalo extremo e então expandido rapidamente.

NEI e colaboradores (1975) ressaltam ainda que as propriedades gerais do gargalo são as mesmas para genes neutros e adaptativos, a menos que estes sejam sujeitos a uma forte seleção natural; isto ocorre porque quando o tamanho populacional é muito pequeno a deriva genética dita a mudança da freqüência gênica.

Os acidentes genéticos inerentes às populações de tamanho pequeno podem ser importantes durante a colonização. Se uma ilha ou pedaço de habitat é colonizado por um ou poucos indivíduos, todos os genes da população assim originada terão derivado daqueles portados pelos fundadores, e de migrações e mutações subseqüentes (FUTUYMA, 1992). No caso específico de populações de ilhas, o efeito do fundador pode ter um papel fundamental. As populações insulares podem possuir uma variação genética reduzida, já que a princípio os fundadores de uma nova colônia portam apenas uma fração da variação genética total da população fonte (FUTUYMA, 1992).

Segundo LEDIG e CONKLE (1983), a deriva é a explicação mais provável para a ausência de variabilidade em Pinus torreyana, que provavelmente deve ter sofrido diminuições de tamanho populacional. Esta espécie endêmica da Califórnia (EUA) só existe em duas populações, uma na costa e a outra na Ilha de Santa Rosa. O efeito de fundador também deve ter operado durante a colonização da população da ilha. Ainda, as populações da ilha e a costeira devem ter se originado de uma população ancestral mais polimórfica, porque elas são fixadas para alelos diferentes. Em um outro estudo, análises de freqüências alozímicas de uma população isolada de Chamaecyparis thyoides (Cupressaceae) mostrou uma baixa variação genética, provavelmente tendo passado por um gargalo; a população deve ter sido fundada por uma ou muito poucas árvores (KUSER et al., 1997). Segundo BUTCHER e colaboradores (1998), os níveis 
extremamente baixos de diversidade genética encontrados em populações isoladas de Acacia mangium sugerem que estas populações foram fundadas em uma base genética estreita, ou experimentaram um declínio em heterozigosidade por causa do isolamento e tamanho pequeno.

Além da diminuição da riqueza alélica e diferenciação populacional, populações pequenas o bastante para experienciar deriva terão também uma maior endogamia (BARRETT e HUSBAND, 1990; ELLSTRAND e ELAM, 1993). A freqüência dos homozigotos aumenta em populações pequenas como o resultado do aumento do cruzamento entre parentes (BARRETT e HUSBAND, 1990), que caracteriza o processo de endogamia (ELLSTRAND e ELAM, 1993, FUTUYMA. 1992).

A freqüência de alelos deletérios recessivos deve ser menor em populações endogâmicas que numa exogâmica já que o endocruzamento os elimina mais rápido, expondo-os na forma homozigota (FUTUYMA, 1992). Assim, se uma população com cruzamento aleatório que abrigue alelos deletérios recessivos se tornar endogâmica, haverá de início uma considerável depressão por endocruzamento (FUTUYMA, 1992), que é um dos maiores efeitos da endogamia (MILLIGAN et al., 1994).

HAWLEY e DeHAYES (1994) encontraram que a heterozigosidade observada em populações pequenas e isoladas de Picea rubens ao sul é mais baixa que em populações situadas ao centro e ao norte de sua distribuição. Diferenciação genética relativamente alta entre populações, níveis de endogamia maiores que o esperado, e evidência de reduzido fluxo gênico entre populações sugerem que a baixa variabilidade genética nas populações ao sul podem ser o resultado de deriva genética seguida de endogamia.

Com o endocruzamento, as freqüências gênicas permanecem as mesmas, mas os genótipos homozigotos têm sua freqüência aumentada. Por outro lado, quando a perda da heterozigosidade é meramente conseqüência do pequeno tamanho populacional, a população permanece em equilíbrio de Hardy-Weinberg (FUTUYMA, 1992).

Populações pequenas e isoladas tornam-se um tema atual devido à crescente fragmentação de ecossistemas nas últimas décadas. A fragmentação do habitat por ação antrópica reduz o habitat contínuo em muitos remanescentes menores e isolados 
espacialmente (YOUNG et al., 1996). Teoricamente, conforme citam os autores, as conseqüências genéticas destas mudanças populacionais são a erosão da variação genética e aumento da divergência genética interpopulacional, através: (1) de um aumento da deriva genética, (2) maior endogamia, (3) fluxo gênico interpopulacional reduzido, (4) aumento da probabilidade de extinção de demes de uma metapopulação. Os autores concluem, através de resultados empíricos, que a redução do tamanho populacional usualmente causa erosão da variação genética (riqueza alélica populacional e heterozigosidade individual), perdas essas mais provavelmente devidas à formação de gargalos e subsequente endogamia em populações pequenas do que a efeitos de deriva genética contínua. Porém, é também já evidente que nem todo evento de fragmentação leva a uma redução da variação genética em plantas.

Populações pequenas devem geralmente perder heterozigosidade mais rapidamente do que populações grandes porque a taxa de perda é aproximadamente igual a 1/2N em cada geração (NEI et al., 1975). Porém, quando estamos avaliando o tamanho populacional, é de importância observar que ele pode diferir do número de indivíduos, já que se alguns desses $\mathrm{N}$ indivíduos não se reproduzirem, ou se eles forem aparentados, a população será menor do ponto de vista genético (FUTUYMA, 1992). Um parâmetro melhor é o $\mathrm{N}_{\mathrm{e}}$, tamanho efetivo populacional, que representa o tamanho de um população ideal, na qual cada indivíduo contribui igualmente ao conjunto gamético, tendo a mesma variação em freqüências alélicas que a população observada (WRIGHT,1931). O tamanho efetivo, e não o número de indivíduos, é que determina a taxa de deriva genética (FUTUYMA, 1992). Qualquer fator que leve alguns indivíduos a deixarem mais descendentes do que outros, reduzirá o tamanho efetivo. O tamanho efetivo da população será ainda mais reduzido se as gerações se sobrepuserem, de modo que os descendentes possam se acasalar com seus pais ou se o tamanho da população flutuar ao longo das gerações (FUTUYMA, 1992). WRIGHT (1931) predisse que a deriva irá alterar substancialmente a organização da variação genética de populações quando $1 / 4$ do $\mathrm{N}_{\mathrm{e}}$ (tamanho efetivo) é muito maior que a taxa de mutação $(\mu)$ e o coeficiente de seleção (s). 
Muitos autores sugerem que os fatores históricos são os principais responsáveis pela estrutura genética de espécies arbóreas. GE et al. (1998), e.g., estudaram Cathaya argyrophylla, uma conífera ameaçada que ocorre na China em populações pequenas em montanhas subtropicais muito separadas, encontrando uma baixa quantidade de variação ao nível populacional, enquanto o nível de diferenciação é bastante alto. Esta estrutura genética peculiar teria sido causada por fatores históricos, que incluem um gargalo severo e subsequente deriva genética durante as glaciações quaternárias e deterioração do habitat e fragmentação após a glaciação. Ainda, conforme os autores, fluxo gênico reduzido e endogamia relativamente alta podem ser fatores que levaram à baixa variabilidade populacional e grande diferenciação genética entre populações. Um outro trabalho é o de BUTCHER et al. (1998), que encontraram evidências de diferenciação genética entre populações de Acacia mangium, o que pode refletir restrições ao fluxo gênico associado com expansões e contrações passadas das florestas tropicais que ocorreram com mudanças climáticas e do nível do mar. McCLENAGHAN e BEAUCHAMP (1986) estudaram a palmeira Washintonia filifera, que mostrou baixos níveis de variabilidade intrapopulacional e de diferenciação genética entre populações. É hipotetizado pelos autores que processos estocásticos reduziram os níveis de variabilidade genética na formação de um refúgio populacional, e a dispersão a partir deste refúgio em habitats favoráveis na formação das populações atuais produziria populações com baixa variabilidade e alta similaridade genética por causa do ancestral comum. Outra possibilidade é a existência de pressões de seleção uniformes favorecendo um grupo estreito de genótipos especializados em populações relictuais ou colonizadoras. QIU e PARKS (1994) conferem a baixa diversidade em Magnolia macrophylla e Magnolia tripetala à endogamia e à deriva genética, bem como a fatores históricos, como o efeito de gargalo causado por extinções durante as glaciações quaternárias, e o efeito do fundador no subsequente reestabelecimento populacional. Efeito de gargalo de garrafa por atividades humanas nos últimos dois séculos também são citados. 


\section{MATERIAIS E MÉTODOS}

\subsection{Caracterização dos locais de estudo}

A Floresta Pluvial Tropical Ombrófila Densa ou, genericamente, Mata Atlântica, situa-se no Estado de São Paulo, sobre a Serrania Costeira (MANTOV ANI, 1993). As Florestas Atlânticas apresentam composição florística e estrutura dependentes de características geológicas, geomorfológicas, pedológicas e climáticas, pretéritas e atuais, de variações locais, da contribuição de floras diversas e da dinâmica da vegetação (MANTOVANI, 1993). Os ecossistemas costeiros apresentam interrelações complexas, estabelecidas notadamente pela rede hidrográfica que drena as serras costeiras, com características estruturais e funcionais que os colocam entre os ecossistemas brasileiros mais frágeis (MANTOVANI, 1992).

A situação da Mata Atlântica é considerada muito grave. Da sua área original de distribuição, a longo de toda a Costa Atlântica, desde o Rio Grande do Norte até o Rio Grande do Sul, pouco resta preservado (LEITÃO Fo cobertura vegetal original reduziu-se a menos de 5\% de seu território, restrita principalmente às escarpas íngremes e de difícil ocupação nas serras costeiras, e às manchas contendo vegetações alteradas, disjuntas e de extensões reduzidas, no interior do Estado (S.M.A., 1989).

Na encosta da Serra do Mar, entre 50 e 90 metros de altitude, ocorre uma formação florestal típica, onde o dossel apresenta 24 a 28 metros de altura e árvores emergentes atingem mais de 30 metros. Observam-se nitidamente mais dois estratos arbóreos; o inferior, com 5 a 10 metros e o médio, com 15 a 20 metros, ambientes onde é encontrada grande diversidade de epifitas (S.M.A., 1996). 
O Parque Estadual da Serra do Mar estende-se do litoral norte do Estado de São Paulo, a partir da divisa com o Rio de Janeiro, até os municípios de Peruíbe e Pedro de Toledo, no litoral sul, envolvendo entre vários outros os municípios de Bertioga e Cubatão. É o maior Parque Estadual Paulista, com 315.390 hectares, e a Unidade de Conservação mais extensa do Estado e com maior área de florestas do domínio da Mata Atlântica. O Parque protege diversas populações de plantas e animais, estando também nele localizadas várias aldeias indígenas guaranis (S.M.A., 1996).

O Arquipélago dos Alcatrazes situa-se no município de São Sebastião $\left(24^{0} 06^{\prime}\right.$ S, $45^{\circ} 41^{\prime} \mathrm{W}$ ), sendo composto pela Ilha dos Alcatrazes, com uma área de 170,4 hectares e distante 34 quilômetros da costa, e por pequenas ilhas, ilhotas, lages e parcéis (POMPÉIA et al., 1993; S.M.A., 1996), sendo composta por formações rupestres, antrópicas e florestais (POMPÉIA et al., 1993). Esta última formação inclui, entre outras, mata com predominância de palmeiras, dada a abundância da palmeira jerivá (Syagrus romanzoffiana), o que confere à mata uma fisionomia característica (POMPÉIA et al., 1993). O Arquipélago dos Alcatrazes é o maior ninhal de aves marinhas do Sudeste brasileiro. Nos Alcatrazes há também uma das maiores concentrações de endemismo do Brasil, com cerca de 17 espécies animais exclusivas (S.M.A., 1996). Uma descrição mais detalhada da flora e fauna do arquipélago são dadas por POMPÉIA et al.(1993) e LUEDERWALDT e FONSECA (1923).

\subsection{Populações estudadas e coleta do material}

Foram estudadas três populações de jerivá - Syagrus romanzoffiana (Chamisso) Glassman, duas situadas no continente, e uma na Ilha dos Alcatrazes. As populações continentais situam-se nos municípios paulistas de São Sebastião (Praia de Fora) e de Bertioga (Praia de Guaratuba, às margens do Rio Itaguaré), distando cerca de $35 \mathrm{~km}$ entre si em linha reta. A Ilha dos Alcatrazes pertence ao município de São Sebastião, localizando-se aproximadamente $30 \mathrm{~km}$ da costa, distando respectivamente cerca de $45 \mathrm{e}$ $35 \mathrm{~km}$ das populações de São Sebastião e Bertioga (figura 1). 

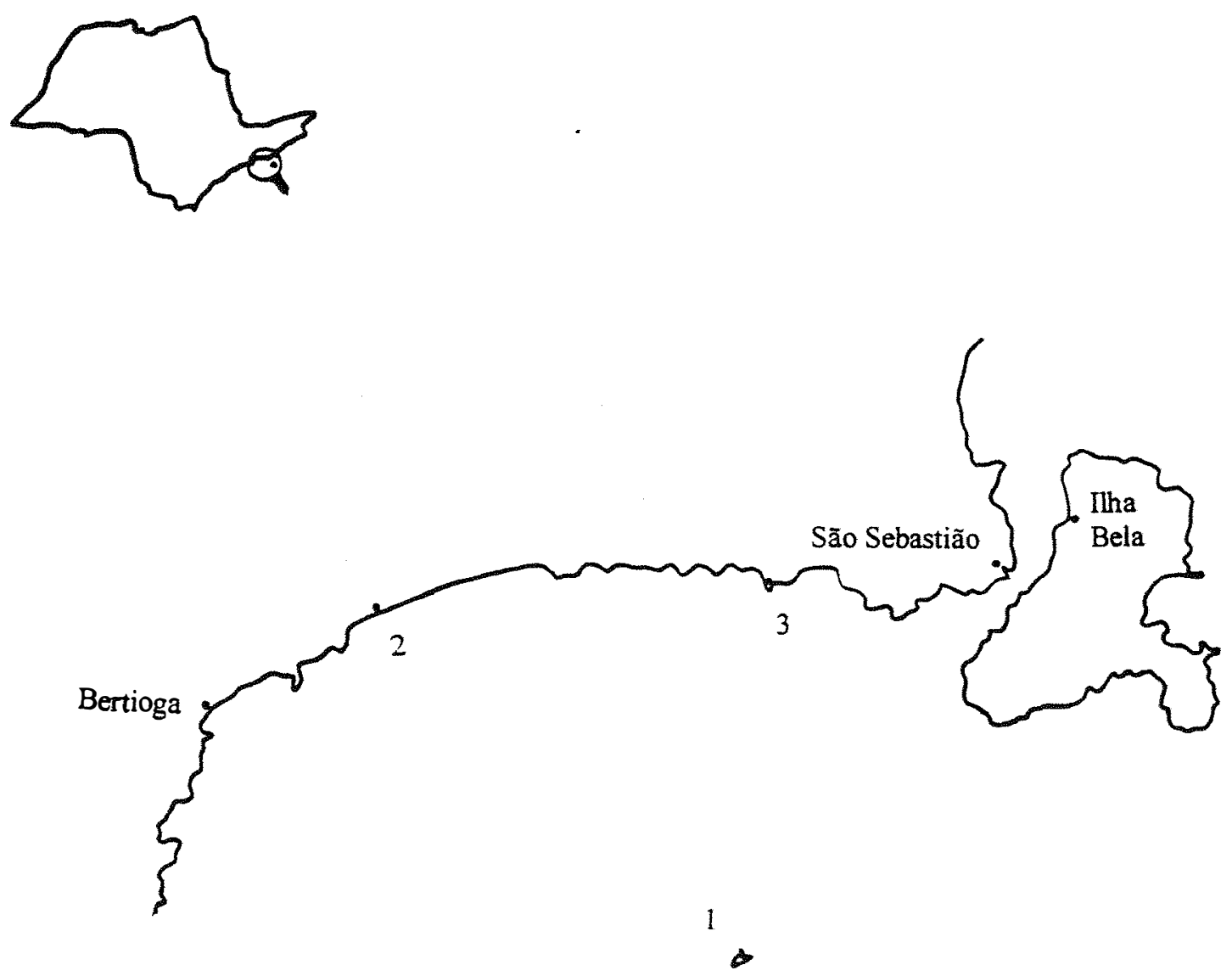

Ilha dos Alcatrazes

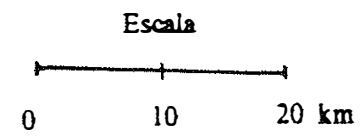

Figura 1: Localização das populações estudadas: 1 - Alcatrazes, 2 - Bertioga, 3 - São Sebastião 
As populações estudadas apresentam uma distribuição disjunta, a assim as populações continentais não são tão interligadas quando tomadas a princípio. Foi preciso percorrer-se toda a região para que elas pudessem ser encontradas. Quando encontrada a população, eram facilmente localizados vários indivíduos; por outro lado, não foi encontrado nenhum indivíduo entre elas. Há, porém, uma diferenciação das populações em relação ao seu tamanho e densidade. Não foi realizada nenhuma mensuração, mas é facilmente observável que a população de Alcatrazes possui um número muito grande de indivíduos, na ordem de milhar, em densidade bastante alta. A população de São Sebastião possui uma área bem restrita e uma densidade muito inferior de indivíduos, e assim sendo, um tamanho menor, que deve ser da ordem de centenas. A população de Bertioga apresenta uma densidade intermediária, em alguns pontos com densidade semelhante a de S. Sebastião e em outros com uma densidade bem maior. Fotos das três populações estudadas são mostradas na figura 2.

Para a realização deste estudo foram efetuadas coletas de material botânico, coletando-se folhas de 20 a 30 indivíduos reprodutivamente ativos (considerados adultos) em cada população. Os indivíduos foram tomados ao acaso nas três áreas estudadas. 5 indivíduos foram também selecionados para observação de suas progênies, possuindo as famílias de 12 a 20 plântulas cada uma. Foram analisados ao todo 80 adultos e 281 plântulas. As plântulas das progênies foram coletadas diretamente nas três áreas, bem abaixo das palmeiras, onde formam um agrupamento típico (banco de plântulas). Procurou-se coletar as progênies de indivíduos que estivessem mais isolados dos outros para assegurar-se melhor sobre sua maternidade. 


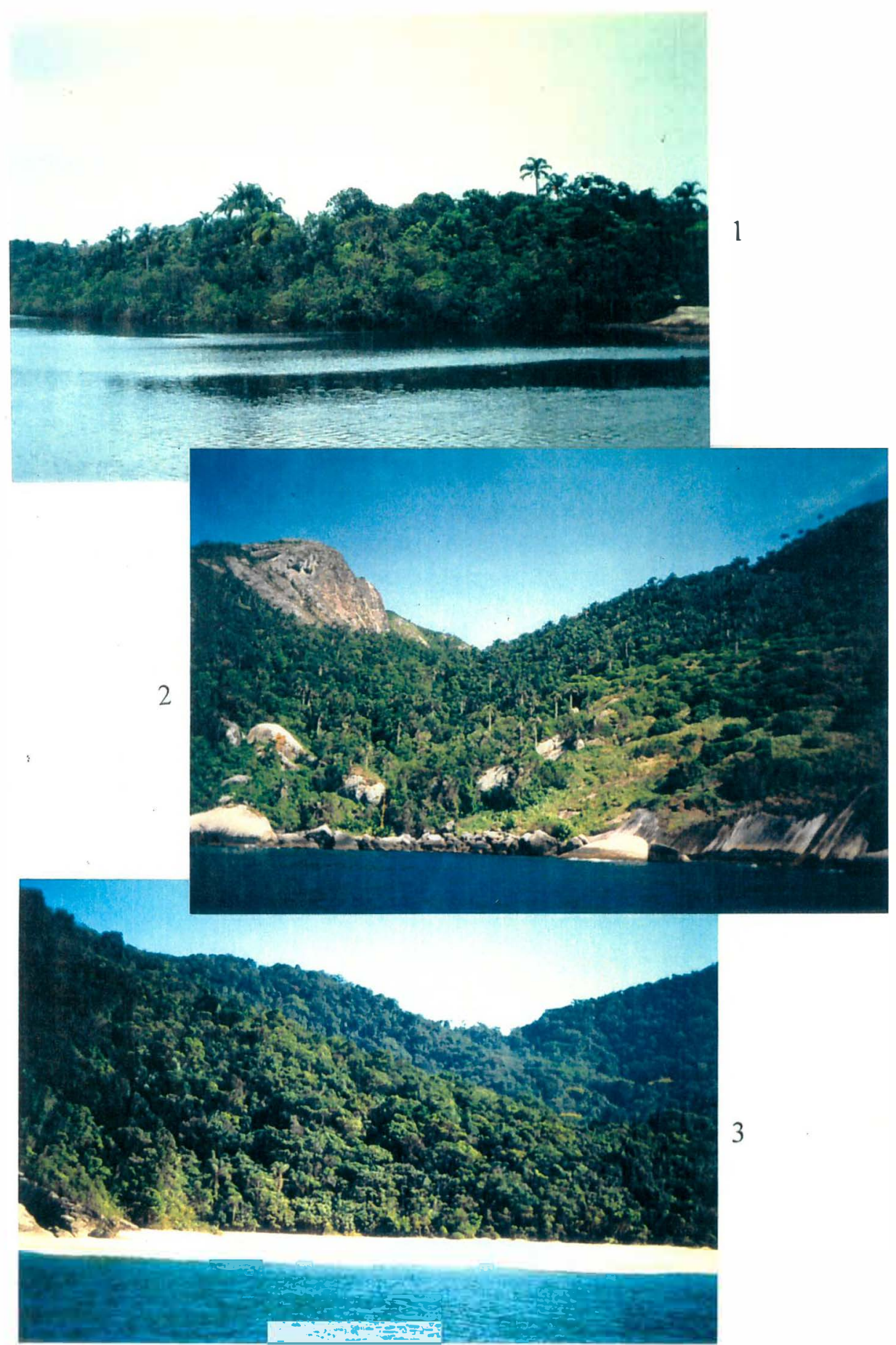

Figura 2: Fotos dos locais de estudo: 1 - Bertioga, 2 - Ilha dos Alcatrazes, 3 - São Sebastião. 


\subsection{Procedimentos de eletroforese de isoenzimas}

Amostras de tecido foliar sadio $(12 \mathrm{mg})$ foram limpas e maceradas com areia lavada, 2 mg de PVP-P e $3 \mathrm{mg}$ de PVP 360, 0,18 ml de solução tampão de extração (tampão no 1 de ALFENAS et al., 1991, porém sem adição de mercaptoetanol). Todas as quantidades de peso e volume foram estimadas. A extração foi realizada com bastões de vidro em placas de porcelana, mantidas resfriadas com gelo durante o processo.

No macerado foram embebidos cortes de papel filtro (Whatman $\mathrm{n}^{\mathbf{0}} 3$ ) de $6 \times 10$ $\mathrm{mm}$ (wicks). Os wicks foram colocados no gel a $5 \mathrm{~cm}$ da borda do gel para o sistema enzimático peroxidase e 2,6 cm para os demais sistemas. Em cada gel foram ainda colocados em cada extremidade um corte de papel filtro embebido em solução de azul de bromofenol a 1\%, a fim de acompanhar a frente de corrida, e ainda um wick de um indivíduo padrão, o mesmo indivíduo em todos os géis, para auxiliar na interpretação das bandas enzimáticas.

O meio suporte empregado foi um gel de dimensões $13 \mathrm{~cm} \times 20 \mathrm{~cm} \times 1 \mathrm{~cm}$, elaborado com $30 \mathrm{~g}$ de penetrose (amido de milho) e $16 \mathrm{~g}$ de amido Sigma, para $350 \mathrm{ml}$ de solução tampão. Após a realização de testes com vários tampões e sistemas enzimáticos, foi utilizado o tampão Lítio-Borato (adaptado de SCANDALIOS, 1969) para os sistemas fosfatase ácida e peroxidase e o Citrato-Morfolina (ALFENAS et al., 1991) para os sistemas restantes, sendo detalhados a seguir:

-Lítio-Borato: Preparar dois tampões, A e B. Tampão A: solução 0,24M de ácido bórico titulado com solução de hidróxido de lítio $2 \mathrm{M}$ para $\mathrm{pH} 8,3$. Tampão $B$ : solução 0,008M de ácido cítrico titulada com trizma base $1 \mathrm{M}$ para $\mathrm{pH} 8,3$. tampão de eletrodo: usar tampão A. tampão de gel: usar solução preparada com tampões A e B, na proporção 1A:9B. 


\section{-Citrato Morfolina:}

tampão de eletrodo: usar solução $0,04 \mathrm{M}$ de ácido cítrico titulada com N-(3 aminopropil) morfolina para $\mathrm{pH} 6,1$.

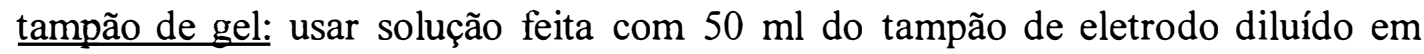
água destilada em q.s.p. $1000 \mathrm{ml}$.

Após o teste de vários sistemas enzimáticos em diferentes tampões de eletrodo e gel, foram definidos os sistemas enzimáticos: fosfatase ácida (ACP-E.C.3.1.3.2), malato desidrogenase (MDH-E.C.1.1.1.37), fosfoglucomutase (PGM-E.C.2.7.5.1), glutamatooxaloacetato transaminase (GOT-2.6.1.1), peroxidase (PER-E.C.1.11.1.7) e xiquimato desidrogenase (SKDH-E.C.1.1.1.25). A preparação das soluções empregadas se deu conforme descrito em ALFENAS et al.(1991), com exceção de GOT, que seguiu indicações de SCANDALIOS (1969). As soluções de coloração destes sistemas encontram-se descritas a seguir:

-ACP: $\alpha$-naftil fosfato de sódio....................................................40 mg fast garnet $\mathrm{GBC}$ salt........................................................50 mg

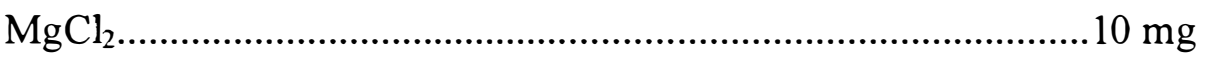
tampão acetato de sódio $0,1 \mathrm{M}$ pH 5,0.................................1000ml Misturar os componentes, adicionar sobre o gel, e incubar no escuro a $37^{\circ} \mathrm{C}$ até as bandas aparecerem.

-MDH: solução DL ácido málico 0,5M pH 8,0............................... ml MTT $10 \mathrm{mg}$

NAD $.10 \mathrm{mg}$

PMS $1 \mathrm{mg}$

tampão tris- $\mathrm{HCl} 0,1 \mathrm{M}$ pH 8,5. q.s.p...1000ml

Misturar os componentes, adicionar sobre o gel, e incubar no escuro a $37^{\circ} \mathrm{C}$ até as bandas aparecerem. 
-PGM: glucose-1-fosfato................................................................150 mg

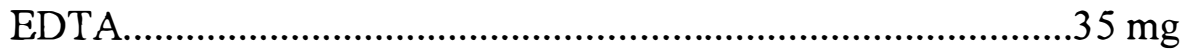

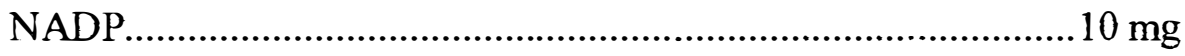

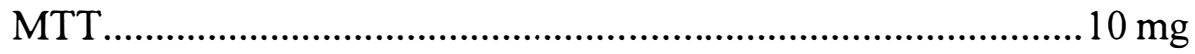

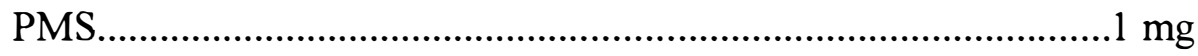

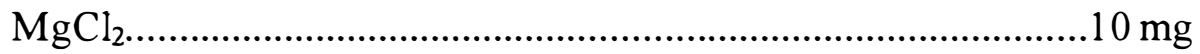
glucose-6-fosfato desidrogenase (G6PDH)........................10 unidades tampão tris-HCl 0,1 M pH 8,0..............................................1000ml Misturar os componentes, adicionar sobre o gel, e incubar no escuro a $37^{\circ} \mathrm{C}$ até as bandas aparecerem.

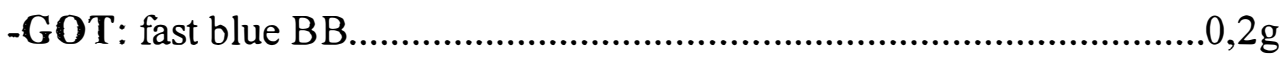

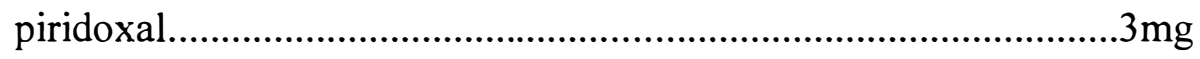

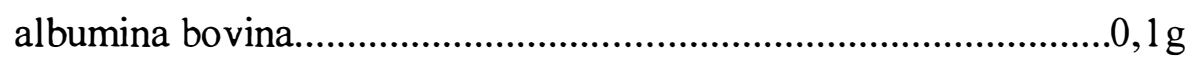
ácido L-aspártico..................................................................... $0,4 \mathrm{~g}$ ácido $\alpha$-cetoglutárico...................................................................06

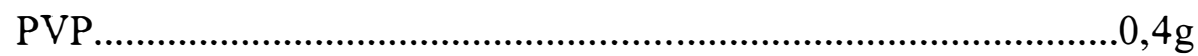
tampão fosfato de sódio $0,2 \mathrm{M} \mathrm{pH} 7.5$.............................p....1000 ml Misturar os componentes, adicionar sobre o gel, e incubar no escuro a $37^{\circ} \mathrm{C}$ até as bandas aparecerem.

OBS: O tampão fosfato de sódio foi feito adicionando $18 \mathrm{ml}$ de tampão C a $42 \mathrm{ml}$ de tampão D. tampão $\mathrm{C}: \quad \mathrm{NaH}_{2} \mathrm{PO}_{4}$..................................27,8g água destilada...............s.p...1000ml

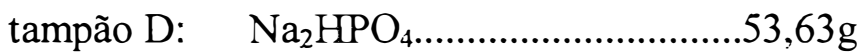
água destilada.............q.s.p...1000ml 


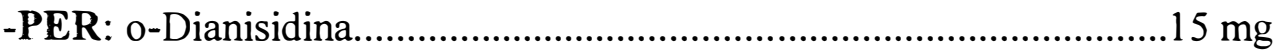

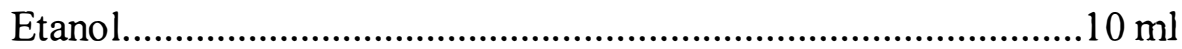

tampão acetato de sódio $0,2 \mathrm{M} \mathrm{pH} \mathrm{5,0 \ldots \ldots \ldots \ldots \ldots ....................p...50} \mathrm{ml}$

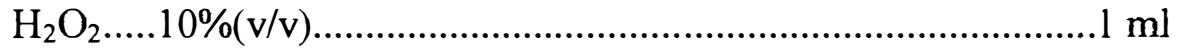

Agitar etanol e dianisidina. Adicionar tampão acetato. adicionar sobre o gel, e incubar no escuro 30 minutos a $37^{\circ} \mathrm{C}$. Adicionar $\mathrm{H}_{2} \mathrm{O}_{2}$ e incubar novamente até as bandas aparecerem.

-SKDH: ácido xiquímico............................................................150mg

MTT ......................................................................10 mg

NADP........................................................................ $10 \mathrm{mg}$

PMS.................................................................................... $\mathrm{mg}$

tampão tris-HCl 0,1M pH8,0......................................p...1000ml

Misturar os componentes, adicionar sobre o gel, e incubar no escuro a $37^{\circ} \mathrm{C}$ até as bandas aparecerem.

Os dados foram registrados através de fotografias tiradas de cada gel assim que a revelação se finalizou. $\mathrm{O}$ registro se deu também através da transparentização dos géis pelo método do bastidor (ALFENAS et al., 1991).

Foram também obtidos os valores de mobilidade relativa (Rf) das bandas (ALFENAS et al., 1991):

$\mathrm{Rf}=\mathrm{d} / \mathrm{D}$

onde d: distância da origem à banda e

D: distância percorrida pela linha frontal do azul de bromofenol . 


\subsection{Análise dos dados}

Para a estimativa de parâmetros que medem a variabilidade genética foi utilizado o programa BIOSYS (SWOFFORD e SELANDER, 1989). Através deste programa foram obtidas as estimativas de freqüências alélicas e os níveis de diversidade (heterozigosidade esperada, porcentagem de locos polimórficos e número de alelos por loco), e foram testados os desvios das freqüências genotípicas em relação ao equilíbrio de Hardy-Weinberg. As freqüências alélicas e os índices de diversidade genética foram calculados com os dados dos indivíduos adultos e de progênies.

\subsubsection{Freqüências alélicas}

As freqüências alélicas foram estimadas contando-se o número de vezes que um alelo é encontrado em cada população, dividindo-se pelo número total de genes da população. Assim:
$p_{k}=n_{k h} / n_{h}$, onde: $p_{k}=$ freqüência do alelo $k$ na população $h$, $n_{k h}=$ número de ocorrências do alelo $k$ na população $h$ e $\mathrm{n}_{\mathrm{h}}=$ número total de alelos na população $\mathrm{h}$.

\subsubsection{Variação genética intrapopulacional}

As medidas de variação genética foram expressas em função do número médio de alelos por loco (A), da porcentagem de locos polimórficos (P), da heterozigozidade esperada ou diversidade genética $\left(\mathrm{H}_{\mathrm{e}}\right)$ e do índice de fixação $\left(\mathrm{F}_{\mathrm{IS}}\right)$. 
-Porcentagem de locos polimórficos $(\mathrm{P})$

A porcentagem de locos polimórficos foi obtida através da divisão do número de locos polimórficos pelo número total de locos analisados. Será considerado loco polimórfico aquele cuja freqüência do alelo mais comum não exceder 0,99 .

-Número médio de alelos por loco (A)

Foi obtido pela somatória de todos os alelos observados dividida pelo número total de locos.

-Heterozigosidade esperada ou diversidade genética $\left(\mathrm{H}_{\mathrm{e}}\right)$

Foi obtida através da expressão:

$H_{e}=1-\sum p_{i}^{2} \quad, \quad$ onde $p_{i}=$ freqüência do alelo $i$.

-Heterozigosidade observada $\left(\mathrm{H}_{\mathrm{o}}\right)$

Proporção do número total de heterozigotos em relação ao número total de indivíduos. Foi obtida da seguinte forma:

$\mathrm{H}_{0}=1-\sum \mathrm{P}_{\mathrm{ii}} \quad, \quad$ onde $\mathrm{P}_{\mathrm{ii}}=$ freqüência de indivíduos homozigotos para alelo i.

- Índice de fixação ( $\left.\mathrm{F}_{\mathrm{IS}}\right)$

$\mathrm{O}$ índice de fixação é definido como o total de heterozigosidade observada em relação à esperada em cruzamentos ao acaso (WRIGHT, 1965):

$$
F_{I S}=\frac{H_{e}-H_{o}}{H_{e}}
$$




\subsubsection{Estrutu ra genética}

A análise da estrutura genética foi efetuada a partir dos coeficientes de coancestralidade $(\theta)$ de Cockerham (COCKERHAM, 1969; VENCOVSKY, 1992), apenas para os dados de progênies. Esta metodologia foi empregada pois permite a avaliação da divergência em diferentes níveis de hierarquia, além de calcular as estimativas com correção para tamanho populacional finito. Os coeficientes de coancestralidade foram obtidos a partir da decomposição dos componentes de variação da análise de variância das frequências alélicas, conforme COCKERHAM (1969). A análise de variância foi realizada com a utilização do programa GDA (LEWIS e ZAYKIN, 1999).

Primeiramente, esta análise foi realizada considerando-se as três populações conjuntamente. Uma nova análise foi realizada tomando-se as populações duas a duas, a fim de observar as divergências entre cada par de populações.

O modelo matemático utilizado foi:

$$
Y_{i j k l}=\mu+p_{i}+f_{j(i)}+a_{k(i j)}+g_{l(i j k)}
$$

onde: $Y_{\mathrm{ijkl}}=$ freqüência do alelo $\mathrm{k}$, no indivíduo $\mathrm{j}$, da família $\mathrm{i}$, da população $\mathrm{h}$ $\mu=$ média geral

$\mathrm{p}_{\mathrm{i}}=$ efeito da população $\mathrm{h} ; \mathrm{h}=1,2, \ldots, \mathrm{a}$

$f_{j(i)}=$ efeito da família i dentro da população $h ; i=1,2, \ldots, b_{i}$

$a_{k(i j)}=$ efeito do indivíduo j, dentro da família i, dentro da população h;

$\mathrm{j}=1,2, \ldots, \mathrm{c}_{\mathrm{ij}}$

$\mathrm{g}_{\mathrm{l}(\mathrm{ijk})}=$ efeito do gene $\mathrm{k}$, dentro do indivíduo $\mathrm{j}$, dentro da família $\mathrm{i}$, dentro da população $h / k=1,2, \ldots, n_{i j k}$ 
A estrutura da análise de variância é mostrada na tabela 4. As estimativas dos componentes de variância foram obtidas a partir da decomposição das esperanças dos quadrados médios:

$$
\begin{aligned}
& \hat{\sigma}_{\mathrm{G}}^{2}=\mathrm{QM}_{\mathrm{G}} \\
& \hat{\sigma}_{1}^{2}=\left(\mathrm{QM}_{1}-\mathrm{QM}_{\mathrm{G}}\right) / 2 \\
& \hat{\sigma}_{\mathrm{F}}^{2}=\left(\mathrm{QM}_{\mathrm{F}}-\mathrm{QM}_{\mathrm{I}}\right) / \mathrm{K}_{1} \\
& \hat{\sigma}_{\mathrm{P}}^{2}=\left[\mathrm{QM}_{\mathrm{P}}-\left(\mathrm{QM}_{\mathrm{I}}-\mathrm{K}_{2} \hat{\sigma}_{\mathrm{F}}^{2}\right)\right] / \mathrm{K}_{3}
\end{aligned}
$$

onde $\mathrm{K}_{1}, \mathrm{~K}_{2}$ e $\mathrm{K}_{3}$ correspondem aos coeficientes das variâncias entre famílias e

\begin{tabular}{|c|c|c|c|}
\hline FV & GL & QM & $\mathrm{E}(\mathrm{QM})$ \\
\hline populações & $a-1$ & $\mathrm{QM}_{\mathrm{P}}$ & $\sigma_{\mathrm{G}}^{2}+2 \sigma_{\mathrm{I}}^{2}+\mathrm{K}_{2} \sigma_{\mathrm{F}}^{2}+\mathrm{K}_{3} \sigma_{\mathrm{P}}^{2}$ \\
\hline famílias/populações & $\sum_{j=1}^{a} b_{j}-a$ & $\mathrm{QM}_{\mathrm{F}}$ & $\sigma_{\mathrm{G}}^{2}+2 \sigma_{1}^{2}+\mathrm{K}_{1} \sigma_{\mathrm{F}}^{2}$ \\
\hline $\begin{array}{l}\text { indivíduos/ famílias/ } \\
\text { populações }\end{array}$ & $\sum_{i=1}^{a} \sum_{j=1}^{b_{i}} c_{i j}-\sum_{i=1}^{a} b_{j}$ & $\mathrm{QM}_{\mathrm{I}}$ & $\sigma_{\mathrm{G}}^{2}+2 \sigma_{1}^{2}$ \\
\hline $\begin{array}{l}\text { genes/ indivíduos/ } \\
\text { famílias/ populações }\end{array}$ & $n \ldots . .-\sum_{i=1}^{a} \sum_{j=1}^{b_{1}} c_{i j}$ & $\mathrm{QM}_{\mathrm{G}}$ & $\sigma_{\mathrm{G}}^{2}$ \\
\hline total & n....-1 & & \\
\hline
\end{tabular}
populações, no modelo hierárquico desbalanceado.

Tabela 4: Esquema de análise de variância de freqüências alélicas no modelo hierárquico desbalanceado para as progênies de Syagrus romanzoffiana.

O significado genético destes componentes pode ser definido em termos das correlações intraclasse, ou coeficientes de coancestralidade, nos diferentes níveis de hierarquia. Assim, conforme COCKERHAM (1969) e VENCOVSKY (1992): 


$$
\begin{aligned}
& \sigma_{\mathrm{P}}^{2}=\mathrm{p}(1-\mathrm{p}) \theta_{\mathrm{P}} \\
& \sigma_{\mathrm{F}}^{2}=\mathrm{p}(1-\mathrm{p})\left(\theta_{\mathrm{F}}-\theta_{\mathrm{P}}\right) \\
& \sigma_{1}^{2}=\mathrm{p}(1-\mathrm{p})\left(\mathrm{F}-\theta_{\mathrm{F}}\right) \\
& \sigma_{\mathrm{G}}^{2}=\mathrm{p}(1-\mathrm{p})(1-\mathrm{F}) \\
& \sigma_{\mathrm{T}}^{2}=\mathrm{p}(1-\mathrm{p})=\sigma_{\mathrm{P}}^{2}+\sigma_{\mathrm{F}}^{2}+\sigma_{1}^{2}+\sigma_{\mathrm{G}}^{2}
\end{aligned}
$$

onde: p: freqüência de um gene em um determinado loco,

$\theta_{\mathrm{P}}$ : média da distância genética entre as populações ou correlação entre freqüências alélicas das plantas de diferentes famílias da mesma população,

$\theta_{\mathrm{F}}$ : coeficiente de parestesco ou coancestralidade das plantas dentro das famílias, ou correlação entre freqüências alélicas de plantas da mesma família, e

F: correlação entre alelos de plantas de diferentes populações, ou coeficiente de endocruzamento de Wright.

Os coeficientes de coancestralidade podem ser obtidos dos componentes de variância por:

$$
\begin{aligned}
& \theta_{\mathrm{P}}=\sigma_{\mathrm{P}}^{2} / \sigma_{\mathrm{T}}^{2} \\
& \theta_{\mathrm{F}}=\left(\sigma_{\mathrm{P}}^{2}+\sigma_{\mathrm{F}}^{2}\right) / \sigma_{\mathrm{T}}^{2} \\
& \theta_{\mathrm{F}}{ }^{\prime}=\sigma_{\mathrm{F}}^{2} /\left(\sigma_{\mathrm{F}}^{2}+\sigma_{\mathrm{I}}^{2}+\sigma_{\mathrm{G}}^{2}\right) \\
& \mathrm{F}=1-\left(\sigma_{\mathrm{G}}^{2} / \sigma_{\mathrm{T}}^{2}\right)=\left(\sigma_{\mathrm{P}}^{2}+\sigma_{\mathrm{F}}^{2}+\sigma_{\mathrm{I}}^{2}\right) / \sigma_{\mathrm{T}}^{2} \\
& \mathrm{f}=\left(\mathrm{F}-\theta_{\mathrm{P}}\right) /\left(1-\theta_{\mathrm{P}}\right)=\left(\sigma_{\mathrm{F}}^{2}+\sigma_{\mathrm{I}}^{2}\right) /\left(\sigma_{\mathrm{F}}^{2}+\sigma_{\mathrm{I}}^{2}+\sigma_{\mathrm{G}}^{2}\right)
\end{aligned}
$$

onde: f: correlação entre alelos de plantas dentro de populações, ou coeficiente de endocruzamento dentro das populações, e

$\theta_{\mathrm{F}}{ }^{\prime}:$ coeficiente de parentesco das plantas dentro das famílias, ou correlação entre freqüências alélicas de diferentes plantas dentro das famílias, considerando a subdivisão em populações. 


\subsubsection{Sistema reprodutivo}

\subsubsection{Equilíbrio de Hardy-Weinberg}

Conhecendo-se as freqüências alélicas pode-se observar também se estas freqüências estão em Equilíbrio de Hardy-Weinberg (EHW). Este modelo estabelece que para uma população de tamanho infinito, com cruzamento aleatório, na qual não estão operando forças de seleção, mutação ou migração, a abundância relativa dos alelos não muda de uma geração para a outra (FUTUYMA, 1992). Se houver algum desvio das freqüências observadas em relação às freqüências esperadas pelo equilíbrio, este é devido a alguma violação das pressuposições ao modelo. Segundo FUTUYMA (1992), as discrepâncias entre uma população ideal de Hardy-Weinberg e as populações reais são os ingredientes da evolução.

O teste de aderência ao EHW foi feito também através do programa BIOSYS. Este programa calcula o desvio da distribuição dos genótipos observados em relação aos esperados segundo o EHW fazendo o uso de três testes: i) $x^{2}$ utilizando todos os genótipos (não agrupado), ii) $x^{2}$ agrupando os genótipos em três classes (classe 1: $\mathrm{n}^{\mathbf{0}} \mathrm{de}$ homozigotos para o alelo mais comum, classe 2: número de heterozigotos entre o alelo mais comum e o mais raro e classe 3: número de homozigotos raros e outros heterozigotos) e iii) teste exato de Fisher.

\subsubsection{Taxa de cruzamento}

A taxa de cruzamento indica se a população está realizando autofecundação ou fecundação cruzada. Quanto mais próxima de 1.0, mais a população está realizando fecundação cruzada. As taxas de cruzamento multilocos e unilocos foram calculadas segundo metodologia de Ritland e Jain (RITLAND e JAIN, 1981), que se baseia em estimativas de máxima verossimilhança, com a utilização do programa MLTR (RITLAND, 1997). 


\subsubsection{Fluxo gênico}

O fluxo gênico foi obtido a partir da fórmula proposta por Crow e Aoki (1984)

$$
\mathrm{F}_{\mathrm{ST}}=\frac{1}{(4 \alpha \mathrm{Nm}+1)} \text { ou } \mathrm{Nm}=\left(\frac{1}{\mathrm{~F}_{\mathrm{ST}}}-1\right) / 4 \alpha, \quad \text { onde } \quad \alpha=\left(\frac{\mathrm{n}}{\mathrm{n}-1}\right)^{2}
$$

sendo Nm: número de migrantes por geração,

$F_{S T}$ :divergência genética entre populações $e$

n: número de populações

Foi utilizado $\hat{\theta}_{\mathrm{P}}$ ao invés de $\hat{\mathrm{F}}_{\mathrm{ST}}$ para cálculo de $\hat{\mathrm{N}} \mathrm{m}$, pois de acordo com COCKERHAM e WEIR (1993), o emprego de $\theta_{\mathrm{P}}$ como estimador da divergência genética entre populações é mais adequado que FST. O fluxo gênico foi estimado com os dados de progênies.

\subsubsection{Tamanho efetivo}

O tamanho efetivo $\left(\mathrm{N}_{\mathrm{e}}\right)$ fó estimado a partir dos componentes de variância das freqüências alélicas (descritas anteriormente, ítem 3.4.3), para os dados de progênies e de adultos. Assim, conforme VENCOVSKY (1992):

$$
\bar{\sigma}_{\mathrm{T}}^{2}=\frac{\sigma_{\mathrm{T}}^{2}}{2 \mathrm{~N}_{\mathrm{e}}} \quad \text { ou } \quad \mathrm{N}_{\mathrm{e}}=\frac{\sigma_{\mathrm{T}}^{2}}{2 \bar{\sigma}_{\mathrm{T}}^{2}},
$$


onde, para progênies:

$$
\begin{array}{ll}
\sigma_{\mathrm{T}}^{2}=\sigma_{\mathrm{p}}^{2}+\sigma_{\mathrm{F}}^{2}+\sigma_{1}^{2}+\sigma_{\mathrm{G}}^{2}=\mathrm{p}(1-\mathrm{p}) & \mathrm{e} \\
\bar{\sigma}_{\mathrm{T}}^{2}=\frac{\sigma_{\mathrm{p}}^{2}}{\mathrm{r}}+\frac{\sigma_{\mathrm{F}}^{2}}{\mathrm{f}}+\frac{\sigma_{\mathrm{I}}^{2}}{\mathrm{i}}+\frac{\sigma_{\mathrm{G}}^{2}}{2 \mathrm{i}}, \text { sendo, } & \text { r:número de populações } \\
& \mathrm{f}: \text { número total de progênies e } \\
& \mathrm{i}: \text { número total de plantas. }
\end{array}
$$

e para os indivíduos adultos:

$$
\begin{aligned}
& \sigma_{\mathrm{T}}^{2}=\sigma_{\mathrm{P}}^{2}+\sigma_{\mathrm{I}}^{2}+\sigma_{\mathrm{G}}^{2}=\mathrm{p}(1-\mathrm{p}) \\
& \bar{\sigma}_{\mathrm{T}}^{2}=\frac{\sigma_{\mathrm{P}}^{2}}{\mathrm{r}}+\frac{\sigma_{\mathrm{I}}^{2}}{\mathrm{i}}+\frac{\sigma_{\mathrm{G}}^{2}}{2 \mathrm{i}},
\end{aligned}
$$

sendo r: número de populações e i: número total de plantas. 


\section{RESULTADOS E DISCUSSÃO}

\subsection{Sistemas enzimáticos}

Foram analisados 6 sistemas enzimáticos, sendo eles ACP, GOT, MDH, PGM, SKDH, PRX, possuindo os sistemas MDH e PRX dois locos cada e os restantes um loco cada. Os locos Mdh1, Mdh2 e Prxl apresentaram-se monomórficos. Os locos Pgm, Skdh e Acp apresentaram dois alelos cada e os locos Got e Prx2 apresentaram três alelos cada, totalizando assim 15 alelos. O loco Got apresentou enzima dimérica, enquanto que os demais polimórficos possuíram enzimas monoméricas. Para as progênies foram analisados os 8 locos, enquanto que para os indivíduos adultos foram analisados dois locos, Got e Pgm, que mostraram as mesmas características que para progênies.

Em virtude do número de locos analisados para os indivíduos adultos ser pequeno, as estimativas dos parâmetros genéticos podem não ser representativos. Outro problema é a ocorrência de desvios padrões muito altos, prejudicando a interpretação dos dados. Infelizmente, o material coletado perdeu a atividade enzimática devido ao tempo prolongado de armazenamento, inviabilizando as análises da maioria dos sistemas enzimáticos, e uma nova coleta não foi possível. Estes dados foram no entanto mantidos por apresentarem-se bastante coerentes com os dados de progênies e de outras espécies arbóreas tropicais. As progênies, por outro lado, estavam em viveiro, podendo sempre ser coletado material fresco para as análises eletroforéticas.

Fotos de zimogramas e suas representações esquemáticas podem ser visualizados respectivamente nas figuras 3 e 4 . 

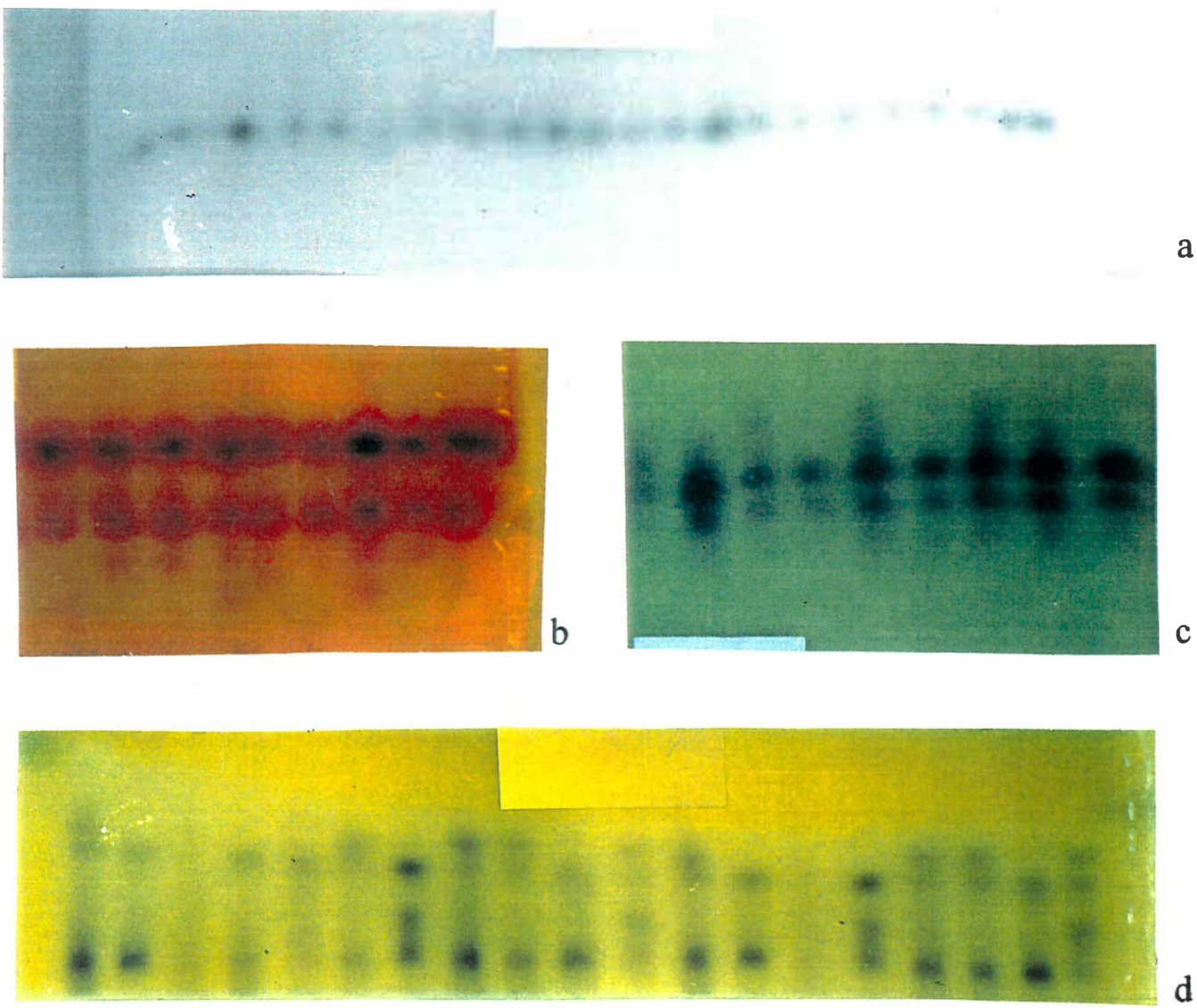

d

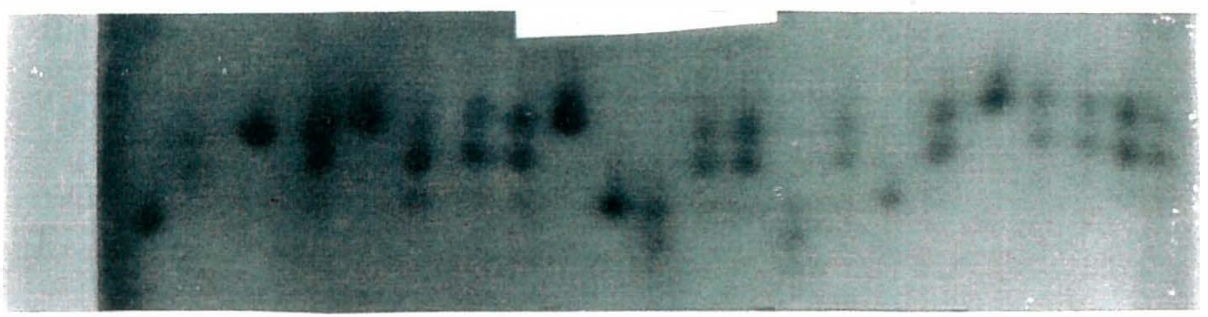

$\mathrm{e}$

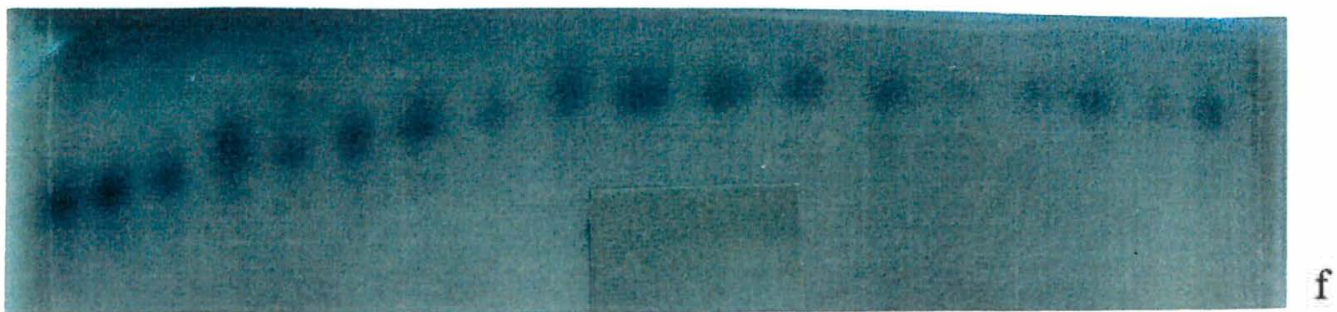

Figura 3: Fotos dos géis, sistemas enzimáticos $\mathrm{SKDH}$ (a), PRX (b), $\mathrm{MDH}$ (c), ACP (d), GOT (e) e PGM (f). 


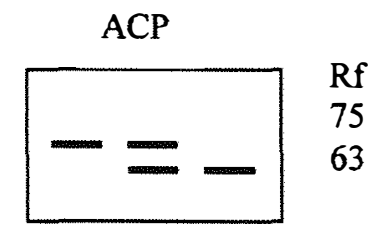

genótipos: $1 \quad 12 \quad 22$

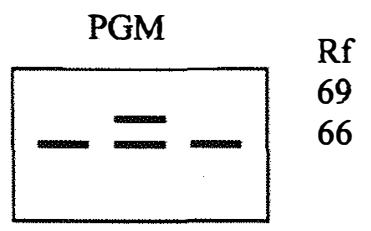

genótipos: $22 \quad 12 \quad 22$

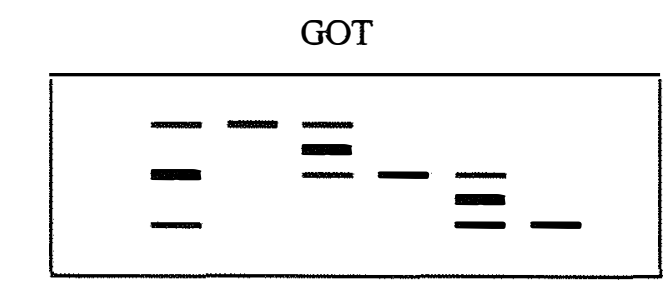

$\begin{array}{lllllll}\text { genótipos: } & 13 & 11 & 12 & 22 & 23 & 33\end{array}$

\begin{abstract}
Rf
88

58

40
\end{abstract}

genótipos: $11 \quad 12 \quad 11$
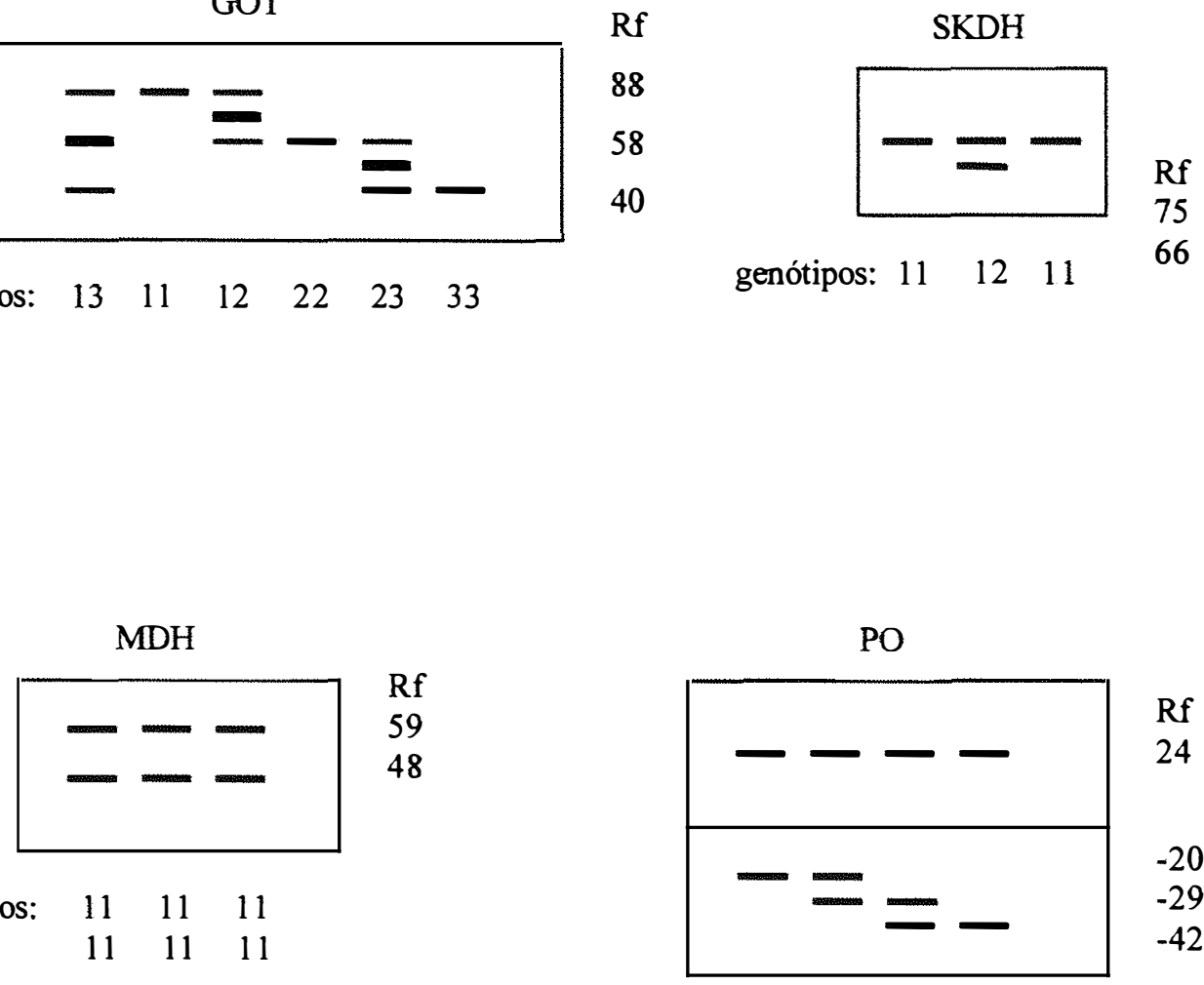

$\begin{array}{lllll}\text { genótipos: } & 11 & 11 & 11 & 11 \\ & 11 & 12 & 23 & 33\end{array}$

Figura 4: Esquemas dos zimogramas dos padrões eletroforéticos de 6 sistemas enzimáticos $(8$ locos $)$ de três populações de Syagrus romanzoffiana. 


\subsection{Freqüências alélicas}

As freqüências alélicas obtidas para os locos analisados para adultos e progênies se encontram na tabela 5 .

Tabela 5: Estimativas de freqüências alélicas de 5 locos alozímicos para progênies e de 2 locos para indivíduos adultos de três populações naturais de Syagrus romanzoffiana.

\begin{tabular}{|c|c|c|c|c|}
\hline \multicolumn{4}{|c|}{ PROGENIES } & \multirow[b]{2}{*}{ São Sebastiāo } \\
\hline Loco & alelo & Alcatrazes & Bertioga & \\
\hline \multirow[t]{2}{*}{ Acp } & 1 & 1,000 & 0,961 & 0,414 \\
\hline & 2 & 0,000 & 0,039 & 0,586 \\
\hline \multirow[t]{3}{*}{ Got } & 1 & 0,250 & 0,495 & 0,786 \\
\hline & 2 & 0,636 & 0,505 & 0,027 \\
\hline & 3 & 0,114 & 0,000 & 0,187 \\
\hline \multirow[t]{2}{*}{ Pgm } & 1 & 0,989 & 0,990 & 1,000 \\
\hline & 2 & 0,011 & 0,010 & 0,000 \\
\hline \multirow[t]{3}{*}{$\operatorname{Prx} 2$} & 1 & 0,442 & 0,420 & 0,137 \\
\hline & 2 & 0,558 & 0,580 & 0,798 \\
\hline & 3 & 0,000 & 0,000 & 0,065 \\
\hline \multirow[t]{2}{*}{ Skdh } & 1 & 0,977 & 1,000 & 1,000 \\
\hline & 2 & 0,023 & 0,000 & 0,000 \\
\hline \multicolumn{5}{|c|}{ ADULTOS } \\
\hline Loco & alelo & Alcatrazes & Bertioga & São Sebastião \\
\hline \multirow[t]{3}{*}{ Got } & 1 & 0,350 & 0,450 & 0,783 \\
\hline & 2 & 0,567 & 0,525 & 0,100 \\
\hline & 3 & 0,083 & 0,025 & 0,117 \\
\hline \multirow[t]{2}{*}{ Pgm } & 1 & 0,900 & 0,725 & 1,000 \\
\hline & 2 & 0,100 & 0,275 & 0,000 \\
\hline
\end{tabular}


A população de São Sebastião apresentou freqüências alélicas distintas das duas outras populações para o loco Acp, possuindo freqüências intermediárias, enquanto que na população da Ilha dos Alcatrazes o alelo 1 se encontra fixado e em Bertioga igual a 0,961. No loco Got, para as progênies, o alelo 2 apresenta uma freqüência mediana para as populações de Alcatrazes e Bertioga, enquanto que em São Sebastião ele possui uma freqüência bastante baixa. Para os adultos também há uma diferença nas freqüências alélicas no loco Got. A população de São Sebastião apresentou um alelo 3 para o loco Prx2, inexistente nas outras duas populações, o mesmo ocorrendo para a população de Alcatrazes, que possui um alelo 2 exclusivo no loco Skdh. Os locos Acp, Skdh e Pgm apresentaram fixação de alelos para pelo menos uma das populações.

Estas oscilações em freqüências alélicas, perdas e fixação de alelos, podem ser um indicativo da ocorrência de deriva genética. Oscilações em freqüências alélicas, quando não existem mecanismos de seleção natural, se desenvolvem através de processos aleatórios. No caso das populações estudadas, se for considerado que elas estejam sujeitas a um ambiente homogêneo, com condições climáticas e de vegetação similares, a seleção natural terá uma atuação reduzida, podendo então a deriva genética influenciar de maneira mais incisiva, resultando na flutuação das freqüências alélicas observadas para o Syagrus romanzoffiana. As variações encontradas, como no loco Acp, no qual um alelo tem freqüência muito alta em algumas populações, e na outra possui freqüência mediana, ou como nos locos Prx2 e Skdh, em que alelos raros de uma ou mais populações desaparecem nas demais, são mais prováveis de terem sido causadas por deriva genética do que por seleção natural.

A análise das freqüências alélicas são muito importantes pois podem refletir melhor os efeitos estocásticos do que a maioria dos parâmetros geralmente utilizados no estudo de genética de populações, já que estes não são muito sensíveis aos alelos de baixa freqüência. Em um estudo com a espécie arbórea tropical Chorisia speciosa (SOUZA, 1997) a autora conclui que os parâmetros genéticos que medem diversidade genética $\left(\hat{\mathrm{H}}_{\mathrm{e}}, \hat{\mathrm{H}}_{\mathrm{o}}, \hat{\mathrm{P}}, \hat{\mathrm{A}} \mathrm{e} \hat{\mathrm{F}}\right)$ não refletem a perda de alelos raros, não sendo bons indicadores de perda genética entre as quatro populações estudadas. Esta perda ficou evidente, porém, a partir da análise direta das freqüências alélicas. 


\subsection{Variação genética intrapopulacional}

O jerivá apresentou, para progênies, uma heterozigosidade esperada média por população $\left(\hat{\mathrm{H}}_{\mathrm{e}}\right)$ igual a 0,140 e número médio de alelos por loco $(\hat{\mathrm{A}})$ igual a 1,59 . A proporção de locos polimórficos ( $\hat{\mathrm{P}}$ ) foi igual a 45,83, considerando freqüência do alelo mais comum equivalente a 0,99 .

Para os indivíduos adultos, os valores de variação genética $\hat{H}_{e}, \hat{A}$ e $\hat{P}$ encontrados foram respectivamente $0,342,2,33$ e 83,33. Apesar de serem considerados apenas locos polimórficos nas análises, o loco Pgm não apresentou-se polimórfico para a população de São Sebastião, tornando $\hat{\mathrm{P}}$ menor do que 100.

Tabela 6: Valores médios populacionais de heterozigosidades esperada $\left(\hat{H}_{e}\right)$ e observada $\left(\mathrm{H}_{\mathrm{o}}\right)$, índice de fixação $\left(\hat{\mathrm{F}}_{\mathrm{IS}}\right)$, número de alelos por loco $(\hat{\mathrm{A}})$ e proporção de locos polimórficos $(\hat{\mathrm{P}})$ de Syagrus romanzoffiana para adultos e progênies das três populações estudadas.

\begin{tabular}{lccccc}
\hline Geração & $\hat{\mathbf{H}}_{\mathbf{e}}$ & $\mathbf{H}_{\mathbf{0}}$ & $\hat{\mathbf{F}}_{\mathrm{IS}}$ & $\hat{\mathbf{A}}$ & $\hat{\mathbf{P}} \%^{\mathrm{a}}$ \\
\hline adultos & 0.342 & 0,361 & $-0,076$ & 2,33 & 83,33 \\
progênies-mesmos locos dos adultos $^{\mathrm{b}}$ & 0,236 & 0,237 & $-0,013$ & 2,17 & 83,33 \\
progênies-todos os locos & 0,140 & 0,126 & 0,096 & 1,59 & 45,83 \\
\hline
\end{tabular}

${ }^{\mathrm{a}}$ freqüência do alelo mais comum não superior a $99 \%$;

${ }^{b}$ progênies considerando apenas os mesmos locos analisados para os adultos 
Os valores de heterozigosidade esperada para indivíduos adultos de Syagrus romanzoffiana foram maiores do que os das progênies, mesmo quando são considerados para o cálculo das estimativas apenas os mesmos locos considerados para os indivíduos adultos (Got e Pgm) (tabela 6). Valores de heterozigozidade esperada superiores para adultos que para progênies sugerem um mecanismo de seleção em favor dos heterozigotos. Resultados deste tipo também foram encontrados para outras espécies arbóreas tropicais, como em Cecropia obtusifolia (ALV AREZ-BUYLLA e GARAY, 1994), Cedrela fissilis (GANDARA, 1996), Chorisia speciosa (SOUZA, 1997), Genipa americana (SEBBEN, 1997) e Euterpe edulis (REIS,1996).

Os valores de variação genética do jerivá são um pouco inferiores ao da média das espécies arbóreas tropicais se considerarmos os valores de progênies, e superiores se considerarmos os resultados dos indivíduos adultos (tabela 7). Esta disparidade foi provavelmente encontrada em função do menor valor geralmente encontrado para as progênies em relação aos adultos, como já discutido, e também porque estes índices são maiores quando utiliza-se apenas locos polimórficos para calcular-se as estimativas.

Considerando os dados de progênies, os valores de diversidade de $S$. romanzoffiana são um pouco baixos, porém se encontram coerentes com os valores obtidos para espécies arbóreas tropicais (tabela 7). Quando são considerados apenas locos polimórficos para o cálculo das estimativas com dados de progênies, os valores para o S. romanzoffiana aproximam-se mais dos valores de espécies de palmeiras (tabela 7). 
Tabela 7- Índices de diversidade genética para palmeiras e espécies arbóreas tropicais .

\begin{tabular}{|c|c|c|c|c|c|}
\hline Categoria & $\mathbf{N}$ & $\hat{\mathbf{A}}$ & $\hat{\mathbf{P}}$ & $\hat{\mathrm{H}}_{\mathrm{e}}$ & fonte \\
\hline \multicolumn{6}{|l|}{ ADULTOS } \\
\hline arbóreas tropicais & $63 ; 88 ; 98$ & 1,9 & 47,4 & 0,178 & MORAES (1997) \\
\hline palmeiras & 5 & 1,7 & 48,9 & 0,196 & $*$ \\
\hline palmeiras não endêmicas & 2 & 1,8 & 65,9 & 0,294 & $* *$ \\
\hline Euterpe edulis $^{\mathrm{a}}$ & 1 & 3,4 & - & 0,452 & REIS (1996) \\
\hline S. romanzoffiana ${ }^{\mathrm{a}}$ & 1 & 2,3 & 83,3 & 0,342 & este trabalho \\
\hline \multicolumn{6}{|l|}{ PROGÊNIES } \\
\hline Syagrus romanzoffiana ${ }^{b}$ & 1 & 1,6 & 45,8 & 0,140 & este trabalho \\
\hline Syagrus romanzoffian $a^{\mathrm{ab}}$ & 1 & 1,9 & 73,3 & 0,224 & este trabalho \\
\hline Acrocomia aculeata ${ }^{\mathrm{ab}}$ & 1 & 2,0 & 100,0 & 0,375 & LOPES et al.. 1992 \\
\hline Euterpe edulis ${ }^{\mathrm{ab}_{*}}$ & 1 & 3,9 & 100,0 & 0,463 & REIS (1996) \\
\hline Chorisia speciosa & 1 & 2,2 & 77,8 & 0,266 & SOUZA (1997) \\
\hline Couratari multiflora & 1 & - & - & 0,429 & LEPSCH-CUNHA (1996) \\
\hline Cryptocaria moschata & 1 & 2,0 & 75,0 & 0,313 & MORAES (1997) \\
\hline Esenbeckia leiocarpa & 1 & 2,0 & 36,4 & 0,176 & SEOANE (1998) \\
\hline Genipa americana & 1 & 1,6 & 50,0 & 0,149 & SEBBEN (1997) \\
\hline Myracrodruon urundeuva & 1 & 1,8 & 37,5 & 0,064 & LACERDA (1997) \\
\hline
\end{tabular}

$\mathrm{N}: \mathrm{n}^{\mathrm{o}}$ de espécies utilizadas no cálculo; $\hat{\mathrm{A}}: \mathrm{n}^{\mathrm{o}}$ de alelos por loco; $\mathrm{P}$ : proporção de locos polimórficos; $\grave{\mathrm{H}}_{\mathrm{e}}$ :heterozigosidade esperada. ${ }^{\mathrm{a}}$ somente locos polimórficos; ' espécies de palmeiras. *EGUIARTE et al. (1992), BENNACER et al (1991),citado por MORAES (1997), McCLENAGHAN e BEAUCHAMP (1986). SHAPCOTT (1998); **EGUIARTE et al. (1992), BENNACER et al. (1991), citado por MORAES (1997). 
Comparando-se as populações entre si (tabela 8), observa-se que para as progênies, os resultados de $\hat{\mathrm{H}}_{\mathrm{e}}, \mathrm{H}_{\mathrm{o}}$ e $\hat{\mathrm{A}}$ não foram diferentes para as três populações. $\mathrm{A}$ proporção de locos polimórficos, no entanto, apresentou-se um inferior $(37,5 \%)$ para a população de São Sebastião do que para as outras duas (50\%).

Para os adultos, a população de Bertioga apresentou um valor de $\hat{\mathrm{H}}_{\mathrm{e}}$ superior ao de São Sebastião, mas similar ao de Alcatrazes. Os desvios padrões foram, porém, bastante altos, especialmente para os indivíduos adultos. Os demais parâmetros apresentaram valores similares para as três populações (tabela 8).

Tabela 8: Heterozigosidades esperada $\left(\hat{\mathrm{H}}_{\mathrm{e}}\right)$ e observada $\left(\mathrm{H}_{\mathrm{o}}\right)$, índice de fixação $\left(\hat{\mathrm{F}}_{\mathrm{IS}}\right)$, número de alelos por loco $(\hat{\mathrm{A}})$ e proporção de $\operatorname{locos}$ polimórficos $(\hat{\mathrm{P}})$ de Syagrus romanzoffiana para adultos e progênies das três populações estudadas. (Desvios padrões estão entre parênteses).

\begin{tabular}{llccccc}
\hline \hline \multirow{2}{*}{ Geração } & População & $\hat{\mathbf{H}}_{\mathbf{e}}$ & $\mathbf{H}_{\mathbf{0}}$ & $\hat{\mathbf{F}}_{\mathrm{IS}}$ & $\hat{\mathbf{A}}$ & $\hat{\mathbf{P}(\%)^{\mathbf{a}}}$ \\
\hline adultos & Alcatrazes & $0,371(0,188)$ & $0,367(0,167)$ & 0.011 & $2,50(0,50)$ & 100 \\
& Bertioga & $0,472(0,061)$ & $0,500(0,150)$ & $-0,059$ & $2,50(0,50)$ & 100 \\
& S.Sebastião & $0,184(0,184)$ & $0,217(0,217)$ & $-0,179$ & $2,00(1,00)$ & 50 \\
\hline \multirow{2}{*}{ progênies } & Alcatrazes & $0,136(0,082)$ & $0,122(0,074)$ & 0,103 & $1,63(0,26)$ & 50 \\
& Berdia & 0,342 & 0,361 & -0.076 & 2,33 & 83,3 \\
& S.Sebastião & $0,147(0,074)$ & $0,137(0,068)$ & 0,068 & $1,63(0,32)$ & 37,5 \\
\hline
\end{tabular}


Esperava-se inicialmente que as populações do continente possuíssem níveis maiores de variação genética que a da Ilha dos Alcatrazes, uma vez que seriam maiores e estariam mais interligadas. Estes resultados não foram encontrados. No entanto, o conhecimento das populações no campo, descrito na metodologia (ítem 3.2), indica que as populações possuem uma distribuição disjunta e assim um certo grau de isolamento entre elas. Os tamanhos das populações paraecem também variar, possuindo a Ilha a população de maior tamanho. Não existem dados, porém, sobre o tamanho, densidade e distribuição das populações; estas observações na área de estudo foram pessoais, merecendo assim uma mensuração mais precisa.

A diversidade gênica $\left(\hat{H}_{\mathrm{e}}\right)$ não é um parâmetro que geralmente responde ao tamanho populacional, sendo este melhor associado aos parâmetros $\hat{\mathrm{A}}$ e $\hat{\mathrm{P}}$ (ELLSTRAND e ELAM, 1993). Em S. romanzoffiana, estas predições foram confirmadas, sendo apenas os valores de $\hat{\mathrm{P}}$ coerentes com o tamanho populacional tanto para adultos quanto para progênies. Seria necessário no entanto uma melhor estimativa do tamanho das populações para uma maior consistência dessas associações.

ODASZ e SAVOLAINEN (1996) apresentam uma visão diferente em relação à geralmente comentada para variação genética em ilhas. Segundo os autores, desde que populações insulares são provavelmente derivadas de uma população fundadora pequena que migrou do continente, a variação genética nas ilhas pode ser maior devido a alelos raros que tornam-se proeminentes em função da deriva genética; por outro lado, a variação genética nas ilhas pode ser menor do que no continente devido à baixa variação genética das populações fundadoras. No caso do jerivá, porém, as populações fundadoras podem ser grandes e assim possuir alta variação genética. 


\subsection{Estrutura genética}

A tabela 9 apresenta os coeficientes de coancestralidade de Cockerham para as três populações estudadas de Syagrus romanzoffiana. Os parâmetros $\hat{\mathrm{f}}, \hat{\mathrm{F}}$ e $\hat{\theta}_{\mathrm{P}}$ correspondem respectivamente às estimativas $\hat{\mathrm{F}}_{\mathrm{IS}}, \hat{\mathrm{F}}_{\mathrm{IT}}$ e $\hat{\mathrm{F}}_{\mathrm{ST}}$ de Wright.

Tabela 9: Coeficientes de coancestralidade para progênies de Syagrus romanzoffiana.

\begin{tabular}{cccccc}
\hline Loco & $\hat{\mathbf{f}}$ & $\hat{\mathbf{F}}$ & $\hat{\theta}_{\mathbf{P}}$ & $\hat{\theta}_{\mathbf{F}}$ & $\hat{\theta}_{\mathbf{F}}^{\prime}$ \\
\hline Acp & 0,083 & 0,592 & 0,527 & 0,555 & 0,059 \\
Got & $-0,160$ & 0,277 & 0,256 & 0,376 & 0,162 \\
Pgm & 0,000 & $-0,005$ & 0,001 & $-0,005$ & $-0,007$ \\
Prx2 & 0,044 & 0,272 & 0,059 & 0,238 & 0,190 \\
Skdh & $-0,010$ & 0,000 & 0,020 & 0,010 & $-0,010$ \\
\hline média & $\mathbf{- 0 , 0 3 3}$ & $\mathbf{0 , 3 5 1}$ & $\mathbf{0 , 2 5 9}$ & $\mathbf{0 , 3 7 2}$ & $\mathbf{0 , 1 5 2}$ \\
\hline
\end{tabular}

$\hat{\mathrm{f}}$ : coeficiente de endocruzamento dentro das populações. $\hat{\mathrm{F}}$ : coeficiente de endocruzamento de Wright. $\hat{\theta}_{\mathrm{P}}$ : divergência genética entre populações. $\hat{\theta}_{\mathrm{F}}$ : coeficiente de parentesco dentro das famílias. $\hat{\theta}_{\mathrm{F}}^{\prime}$ : coeficiente de parentesco dentro das famílias, considerando a subdivisão em populações.

O valor de $\hat{\theta}_{\mathrm{F}}$ para as progênies de $S$. romanzoffiana foi alto, o que mostra uma grande divergência entre as famílias. $\hat{\theta}_{\mathrm{F}}$ é um parâmetro que, segundo VENCOVSKY (1992), é igual a $1 / 8(0,125)$ em famílias de meios irmãos, $1 / 4(0,250)$ em irmãos completos e 1 em autógamas. Em Syagrus romanzoffiana o $\hat{\theta}_{\mathrm{F}}^{\prime}$ foi igual a 0,152 , indicando que há um pouco mais de parentesco do que em famílias de meios-irmãos, mas que não chegam ao de irmãos completos. Isto pode ter sido causado pela ocorrência de cruzamentos biparentais, ou seja, progênies formadas pelo cruzamento do mesmo pai com a mesma $\mathrm{rr}$ 
$\mathrm{O}$ valor de $\hat{\theta}_{\mathrm{P}}$ foi bastante elevado para progênies, o que indica uma grande divergência entre as populações em estudo. $O$ valor de $\hat{\mathrm{f}}$ foi muito baixo e ligeiramente negativo, e assim quase não existe endocruzamento dentro das populações. Desta forma, o alto valor de $\hat{\mathrm{F}}$ encontrado analisando-se as três populações conjuntamente é devido à alta divergência interpopulacional $\left(\hat{\theta}_{\mathrm{P}}\right)$.

Esta alta divergência interpopulacional encontrada, porém, não foi ocasionada igualmente por todas as populações. Isto pode ser observado através da estrutura genética tomando-se duas populações de cada vez (tabela 10).

Tabela 10: Coeficientes de coancestralidade tomando-se as populações duas a duas.

\begin{tabular}{cccc}
\hline populações & $\hat{\mathrm{f}}$ & $\hat{\mathrm{F}}$ & $\hat{\theta}_{\mathrm{p}}$ \\
\hline Alcatrazes - Bertioga & $-0,038$ & 0,144 & 0,001 \\
Alcatrazes - S.Sebastião & $-0,003$ & 0,449 & 0,385 \\
Bertioga - S.Sebastião & $-0,060$ & 0,383 & 0,296 \\
\hline \hline$\hat{\mathrm{f}}$ :coeficiente de endocruzamento dentro das populações. $\hat{\mathrm{F}}$ : coeficiente de \\
endocruzamento de Wright. $\hat{\theta}_{\mathrm{p}}$ : divergència genética entre populações.
\end{tabular}

Pode-se observar que as populações de Alcatrazes e São Sebastião apresentam o maior $\hat{\theta}_{\mathrm{P}}$ para progênies possuindo uma maior variação genética entre populações do que as outras combinações de populações. Alcatrazes e Bertioga são as populações que possuem uma menor divergência genética entre populações. Desta forma, as populações de Alcatrazes e Bertioga são mais similares entre si e as populações de Alcatrazes e São Sebastião são as mais divergentes.

Esperava-se, porém, que a população da Ilha dos Alcatrazes possuisse uma maior divergência em relação às populações continentais e estas uma maior semelhança entre si, em função do isolamento geográfico da primeira. 
Uma possibilidade para a formação da população de S. romanzoffiana na Ilha dos Alcatrazes é a colonização da Ilha após o restabelecimento do nível do mar com o degelo depois da última glaciação, há aproximadamente 8 mil anos. A deriva genética se estabeleceria com o efeito do fundador. Desta forma, a população da Ilha deveria ter se formado a partir de indivíduos de pouco parentesco e alta variação, já que possui variação genética relativamente alta e alelos exclusivos.

Alternativamente, o jerivá poderia ter colonizado a área que daria origem à Ilha dos Alcatrazes na ocasião do abaixamento do mar e lá permanecido, quando o nível do mar subiu novamente. Nesta formação da população também haveria a influência de deriva genética, uma vez que o tamanho populacional seria reduzido, e apenas uma amostra da população seria deixada na Ilha. Mas a deriva poderia ser bastante enfraquecida se a população da Ilha tiver sempre sido grande, havendo assim uma menor redução do tamanho populacional; o isolamento, porém, se manteria. Com a capacidade do jerivá de colonizar áreas abertas e nestas situações apresentar grande densidade populacional, esta colonização é passível de ter ocorrido.

Nestas duas possibilidades, o número grande de indivíduos colonizadores associado com a alogamia preferencial seria responsável pela preservação de grande parte da variação genética dentro da população.

Em qualquer uma destas possibilidades, pode-se analisar a estrutura populacional na ausência ou presença de fluxo gênico atual. Se houver fluxo gênico corrente, ele deve estar ocorrendo entre as populações da Itha dos Alcatrazes e Bertioga, uma vez que estas possuem baixo $\hat{\theta}_{p}$, e ocorrendo apenas de maneira muito sutil entre a Ilha e São Sebastião e entre Bertioga e São Sebastião, que possuem alta divergência. O fluxo gênico estaria assim sobrepondo o mar, mas apenas entre a Ilha e Bertioga, e encontrando barreiras entre as populações continentais e entre a Ilha e São Sebastião. 
$\mathrm{Na}$ ausência de fluxo gênico atual, pode-se considerar que a população da Ilha se formou a partir da população de Bertioga, ou de uma população ancestral comum às duas populações, dada a pouca diferença genética (baixo $\hat{\theta}_{\mathrm{p}}$ ) entre elas. Já a população de São Sebastião deve ter se formado a partir de uma base genética diferente, possuindo uma ligação mais antiga com as outras duas populações. Na ausência de fluxo gênico atual entre a Ilha e o continente, a baixa divergência entre a população da Ilha a população de Bertioga encontrada indica que tempo de isolamento no qual a população de Alcatrazes se encontra é pequeno, não sendo suficiente para causar uma grande diferença entre esta e demais populações.

Em relação às populações continentais, uma possibilidade é que elas tenham se originado a partir de gargalos de garrafa de uma população de distribuição mais contínua, e assim a divergência genética atual seria conseqüência direta da restrição do tamanho populacional. Neste caso, seria necessário saber se há populações com distribuição contínua na área de ocorrência da espécie ou evidências de que isto possa ter ocorrido no passado. Já se a distribuição da espécie não for contínua, esta divergência seria devida fundamentalmente ao baixo fluxo gênico interpopulacional.

Uma discussão mais aprofundada sobre a atuação do fluxo gênico na estrutura genética das populações estudadas segue no ítem 4.6.

O padrão de organização da variação genética observado para S. romanzoffiana não é o comumente encontrado em espécies arbóreas tropicais, que possuem geralmente alta variação genética dentro de populações e baixa entre populações. Contudo, há casos em que são encontrados altos níveis de $\hat{\mathrm{F}}_{\mathrm{ST}}$, como em Chorisia speciosa (SOUZA, 1997) e Cryptocaria moschata (MORAES, 1997). A tabela 11 mostra alguns exemplos de valores de divergência genética para espécies arbóreas tropicais. 
Tabela 11: Divergência genética em algumas espécies arbóreas tropicais

\begin{tabular}{llll}
\hline \multicolumn{1}{c}{ Espécie } & $\hat{\mathrm{F}}_{\mathrm{ST}}$ & $\hat{\theta}_{\mathrm{P}}$ & \\
\hline Aspidosperma polineuron & 0,061 & & \multicolumn{1}{c}{ Fonte } \\
Astrocaryum mexicanum & 0,039 & & EGUIARTE et al. (1992) \\
Cecropia obtusifolia & 0,029 & & ALVAREZ-BUYLLA e GARAY (1994) \\
Cedrela fissilis & 0,089 & & GANDARA (1997) \\
Chorisia speciosa & 0,183 & & SOUZA (1997) \\
Cryptocaria moschata & 0,107 & 0,123 & MORAES (1997) \\
Esenbeckia leiocarpa & 0,005 & & SEOANE (1998) \\
Euterpe edulis & 0,031 & 0,023 & REIS (1996) \\
Genipa americana & & 0,006 & SEBBEN (1997) \\
Hevea brasiliensis & 0,007 & & PAIVA (1992) \\
Myracrodruon urundeuva & 0,035 & & MORAES (1992) \\
Ocotea tenera & 0,128 & & GIBSON E WHEELWRIGHT (1995)* \\
Psycotria faxlucens & 0,026 & & PÉREZ-NASSER et al. (1993) \\
Pterocarpus macrocarpus & 0,121 & & LIENGSIRI et al. (1995)* \\
Syagrus romanzoffiana & & 0,259 & este trabalho \\
\hline A & & & \\
\hline
\end{tabular}

$\hat{\theta}_{\mathrm{P}}$ : divergência genética entre populações (WRIGHT, 1951); $\hat{\theta}_{\mathrm{P}}$ : divergência genética entre populações (COCKERHAM,1969). * citado por MORAES (1997) 
O Syagrus romanzoffiana apresenta assim um valor de divergência genética interpopulacional que está entre os maiores entre espécies arbóreas tropicais. A alta divergência genética entre populações, estimada por $\hat{f}$. e o baixo endocruzamento dentro de populações, estimado por $\hat{f}$, encontrados para a palmeira em estudo estão de acordo com a ação de deriva genética, já que são conseqüências importantes deste evento aleatório (FUTUYMA, 1992). Sendo aleatória, a deriva pode levar cada população a possuir uma freqüência alélica diferente das demais, e assim causar uma grande divergência genética entre as populações. Desta maneira, a alta divergência encontrada entre as populações, especialmente entre São Sebastião e as outras duas, indicam a atuação de deriva na estrutura genética das populações de Syagrus romanzoffiana estudadas.

De fato, variação genética descontínua pode ocorrer por causa do isolamento de populações disjuntas e deriva genética (MILLAR e LIBBY, 1991). Nesse caso, segundo os autores, ambientes similares não são previsivelmente associados com combinações particulares de variação genética, e a seleção não tem grande atuação. Os autores não descartam a possibilidade de ocorrência de seleção, mas consideram que o seu papel é menos óbvio. Apesar dos fatores seletivos diferirem entre populações, o isolamento e deriva genética são provavelmente mais importantes na produção destes padrões de variação populacional. Este é provavelmente o caso de Syagrus romanzoffiana.

SOUZA (1997) sugeriu a associação de altos índices de $\hat{\mathrm{F}}$ com a ação de deriva genética em Chorisia speciosa, estudada em fragmentos florestais no interior do Estado de São Paulo. A associação entre altos níveis de variação interpopulacional e baixos níveis de variação intrapopulacional com deriva genética em espécies arbóreas já foi efetuada por vários autores (MORAN e HOPPER, 1983; PETERS et al., 1990; KITAMURA e RAHMAN, 1992; ROCHA e LOBO, 1996; GE et al., 1998; e.g.). 


\subsection{Sistema reprodutivo}

\subsubsection{Equilíbrio de Hardy-Weinberg}

Para as três populações estudadas, a maioria dos locos encontram-se em equilíbrio de Hardy-Weinberg, com exceção do loco Prx2 na população de Alcatrazes. Os valores de qui-quadrado e as probabilidades exatas de Fisher dos testes de aderência ao equilíbrio estão nas tabelas abaixo (tabela 12 a 14).

Tabela 12: Testes qui-quadrado e exato de Fisher para os desvios de Hardy-Weinberg, para a população de Syagrus romanzoffina da Ilha dos Alcatrazes.

\begin{tabular}{lcccccc}
\hline loco & genótipos & fo & fe & $\mathbf{x}^{2}$ & $\mathbf{x}^{2}$ (agrup) & P (Fisher) \\
\hline \multirow{2}{*}{ Got } & 1 & 34 & 35,636 & & & \\
& 2 & 44 & 40,727 & - & 0,336 & 0,644 \\
\hline \multirow{2}{*}{ Pgm } & 3 & 10 & 11,636 & & & \\
& $1-1$ & 0 & 0,011 & & & 1,000 \\
\hline \multirow{3}{*}{ Prx2 } & $1-2$ & 2 & 1,977 & & & \\
& $2-2$ & 86 & 86,011 & 0,000 & & $0,038^{*}$ \\
\hline \multirow{3}{*}{ Skdh } & $1-1$ & 20 & 15,260 & & & \\
& $1-2$ & 29 & 38,481 & & - & 1,000 \\
\hline
\end{tabular}

genótipo 1: homozigotos para o alelo mais comum; genótipo 2 heterozigotos entre o alelo mais comum e alelos raros; genótipo 3: heterozigotos raros e outros heterozigotos. fo: freqüência observada; fe: freqüência esperada; $x^{2}$ : qui-quadrado para dados não agrupados; $x^{2}$ (agrup): Quiquadrado para dados agrupados; P: probabilidade do teste exato de Fisher. *significativo a 5\%. 
Tabela 13: Testes qui-quadrado e exato de Fisher para os desvios de Hardy-Weinberg, para a população de Syagrus romanzoffina de Bertioga.

\begin{tabular}{ccrllll}
\hline loco & genótipos & fo & fe & $\mathbf{x}^{2}$ & $\mathbf{x}^{2}$ (agrup) & P (Fisher) \\
\hline \multirow{2}{*}{ Acp } & $1-1$ & 83 & 83,136 & & & \\
& $1-2$ & 7 & 6,728 & & - & 1,000 \\
\hline \multirow{3}{*}{ Got } & $2-2$ & 0 & 0,136 & 0,000 & & \\
& $1-1$ & 25 & 23,753 & & & 0,684 \\
\hline \multirow{3}{*}{ Pgm } & $1-2$ & 46 & 48,495 & & - & \\
& $2-2$ & 26 & 24,753 & 0,128 & & 1,000 \\
\hline \multirow{2}{*}{ Prx2 } & $1-1$ & 0 & 0,010 & & & \\
& $1-2$ & 2 & 1,980 & & - & 0,096 \\
\hline
\end{tabular}

genótipo 1: homozigotos para o alelo mais comum; genótipo 2 heterozigotos entre o alelo mais comum e alelos raros; genótipo 3: heterozigotos raros e outros heterozigotos. fo: freqüência observada; fe: freqüência esperada; $x^{2}$ : qui-quadrado para dados não agrupados; $x^{2}$ (agrup): quiquadrado para dados agrupados; P: probabilidade do teste exato de Fisher

Tabela 14: Testes qui-quadrado e exato de Fisher para os desvios de Hardy-Weinberg, para a população de Syagrus romanzoffina de São Sebastião.

\begin{tabular}{lcccccc}
\hline loco & genótipos & fo & fe & $\mathbf{x}^{2}$ & $\mathbf{x}^{2}$ (agrup) & P (Fisher) \\
\hline Acp & $1-1$ & 18 & 14,897 & & & \\
& $1-2$ & 36 & 42,207 & & - & 0,186 \\
\hline Got & $2-2$ & 33 & 29,897 & 1,453 & & \\
& 1 & 55 & 56,179 & & & 0,754 \\
& 2 & 33 & 30,643 & - & 0.231 & \\
\hline Prx2 & 3 & 3 & 4,179 & & & 0,735 \\
& 1 & 54 & 53,440 & & & \\
& 2 & 26 & 27,119 & - & 0.015 & 0 \\
\hline
\end{tabular}

genótipo 1: homozigotos para o alelo mais comum; genótipo 2 heterozigotos entre o alelo mais comum e alelos raros; genótipo 3: heterozigotos raros e outros heterozigotos. fo: freqüência observada; fe: freqüência esperada; $x^{2}$ : qui-quadrado para dados não agrupados; $x^{2}$ (agrup): Quiquadrado para dados agrupados; P: probabilidade do teste exato de Fisher 
Quando a população é finita, mas os cruzamentos são aleatórios, têm-se a manutenção do EHW e da proporção de heterozigotos (CROW e KIMURA, 1970, FUTUYMA, 1992). Assim, a situação de equilíbrio encontrada para a maioria dos locos nas três populações indica a ocorrência de acasalamentos ao acaso entre as plantas, e uma ausência da ação de migração, seleção e deriva dentro das populações.

\subsubsection{Taxas de cruzamento multilocos e unilocos}

A tabela 15 mostra as taxas de cruzamento multilocos e unilocos para cada população. A taxa de cruzamento multilocos não diferiu de 1 para todas as populações estudadas. A taxa de cruzamento multilocos média para as três populações foi 0,918 para este evento reprodutivo, mostrando-se o Syagrus romanzoffiana uma espécie preferencialmente alógama.

A comparação entre a taxa de cruzamento multilocos e unilocos média possibilita a caracterização de cruzamentos entre aparentados e/ou autofecundação, conforme discutem RITLAND e EL-KASSABY (1985). A diferença entre as taxas multilocos e unilocos são muito pequenas, indicando que praticamente não há cruzamento entre indivíduos aparentados. A $\hat{\mathrm{t}}_{\mathrm{m}}$ próxima a 1 sugerem também a inexistência de autofecundação nas populações estudadas. 
Tabela 15: Taxa de cruzamento por progênie ( $\mathrm{t})$ e taxas de cruzamento multilocos $\left(\hat{t}_{m}\right)$ e unilocos $\left(\hat{t}_{s}\right)$ de Syagrus romanzoffiana para as populações de Alcatrazes, Bertioga e São Sebastião.(Os desvios padrões estão entre parênteses.)

\begin{tabular}{|c|c|c|c|c|c|}
\hline população & n $^{o}$ prog. & $\mathbf{t}$ & $\hat{\mathbf{t}}_{\mathrm{m}}$ & $\hat{\mathbf{t}}_{\mathrm{s}}$ & $\hat{\mathbf{t}}_{\mathbf{m}}-\hat{\mathbf{t}}_{\mathrm{s}}$ \\
\hline Alcatrazes & $\begin{array}{l}\text { P10 } \\
\text { P31 } \\
\text { P32 } \\
\text { P33 } \\
\text { P34 }\end{array}$ & $\begin{array}{l}1,74(0,44) \\
1,28(0,21) \\
0,13(0,27) \\
0,54(0,14) \\
0,00(0,00)\end{array}$ & $1,077(0,146)$ & $0,973(0,162)$ & $0,104(0,059)$ \\
\hline Bertioga & $\begin{array}{l}\text { P11 } \\
\text { P12 } \\
\text { P15 } \\
\text { P21 } \\
\text { P30 }\end{array}$ & $\begin{array}{l}1,90(0,42) \\
0,12(0,08) \\
0,68(0,11) \\
0,06(0,06) \\
1,18(0,26)\end{array}$ & $0,845(0,167)$ & $0,819(0,170)$ & $0,027(0,032)$ \\
\hline S.Sebastião & $\begin{array}{l}\text { P35 } \\
\text { P38 } \\
\text { P39 } \\
\text { P44 } \\
\text { P51 }\end{array}$ & $\begin{array}{c}0,50(0,19) \\
1,43(0,30) \\
0,76(0,62) \\
* * \\
0,32(0,24)\end{array}$ & $0,832(0,309)$ & $0,803(0,324)$ & $0,029(0,101)$ \\
\hline média & & 0,76 & 0,918 & 0,865 & 0,053 \\
\hline
\end{tabular}

**não convergente. $\mathrm{n}^{0}$ prog.: número da progênie.

Os resultados mostraram uma grande diferença das taxas de cruzamento entre indivíduos, que assumiram valores tão discrepantes quanto 0,00 e 1,00. Os indivíduos variaram assim da alogamia completa a autogamia, sendo que esta variação ocorreu em todas as populações. Apesar de apresentar alogamia preferencial, a espécie parece possuir um sistema reprodutivo que suporta a autofecundação.

O jerivá apresentou taxa de cruzamento dentro dos valores geralmente obtidos para espécies arbóreas tropicais e palmeiras. Taxas de cruzamento multilocos de algumas espécies arbóreas tropicais são listadas na tabela 16 . 
Tabela 16: Taxa de cruzamento multilocos $\left(\hat{\mathrm{t}}_{\mathrm{m}}\right)$ para espécies arbóreas tropicais.

\begin{tabular}{lll}
\hline Espécie & $\hat{\mathbf{t}}_{\mathbf{m}}$ & fonte \\
\hline Astrocaryum mexicanum & 1,00 & EGUIARTE et al.(1992) \\
Acrocomia aculeata $^{*}$ & 0,85 & LOPES et al.. 1992 \\
Bauhinia forficata & 0,98 & SANTOS (1994) \\
Bertholletia excelsa & 0,85 & O'MALLEY et al. (1988) \\
Cecropia obtusifolia & 0,97 & ALVAREZ-BLYLLA e GARAY (1994) \\
Cedrela fissilis & 0,92 & GANDARA (1997) \\
Chorisia speciosa & 0,88 & SOUZA (1997) \\
Couratari multiflora & 0,95 & LEPSCH-CUNHA(1996) \\
Cryptocarya moschata & 0,86 & MORAES (1997) \\
Euterpe edulis & 0,99 & REIS (1996) \\
Psycotria faxlucens & 0,99 & PĖREZ-NASSER et al.(1993) \\
Syagrus romanzoffiana & 0,92 & este trabalho \\
\hline \hline
\end{tabular}

* Palmeiras

Estudos adicionais tomando famílias de ouros eventos reprodutivos são importantes para observar se este comportamento se repete ou apresenta alguma variação temporal.

\subsection{Fluxo gênico}

As estimativas de fluxo gênico aparente para as três populações e para cada par de populações são mostradas nas tabelas 17 e 18, respectivamente. Esta medida estima o fluxo gênico aparente e não real pois é uma medida indireta, obtida a partir de divergência genética. 
Tabela 17: Fluxo gênico $(\mathrm{Nm})$ por loco e médio obtido a partir de estimativas de divergência genética $\left(\hat{\theta}_{\mathrm{P}}\right)$ para progênies de três populações naturais de Syagrus romanzoffiana.

\begin{tabular}{ccc}
\hline \hline loco & $\hat{\boldsymbol{\theta}}_{\mathrm{P}}$ & $\mathbf{N m}$ \\
\hline Acp & 0,527 & 0,100 \\
Got & 0,256 & 0,323 \\
Pgm & 0,001 & 78,972 \\
Prx2 & 0,059 & 1,760 \\
Skdh & 0,019 & 5,581 \\
\hline médio & $\mathbf{0 , 2 5 9}$ & $\mathbf{0 , 3 1 7}$ \\
\hline
\end{tabular}

Tabela 18: Fluxo gênico $(\mathrm{Nm})$ obtido a partir de estimativas de divergência genética $\left(\hat{\theta}_{\mathrm{P}}\right)$ para progênies de três populações naturais de Syagrus romanzoffiana tomadas duas a duas.

\begin{tabular}{lcr}
\hline \hline Populações & $\hat{\boldsymbol{\theta}}_{\mathrm{p}}$ & $\mathbf{N m}$ \\
\hline Alcatrazes e Bertioga & 0,001 & 48,089 \\
Alcatrazes e S. Sebastião & 0,385 & 0,100 \\
Bertioga e S. Sebastião & 0,296 & 0,148 \\
\hline \hline
\end{tabular}

Os resultados mostram um fluxo gênico bastante baixo entre as três populações. Segundo WRIGHT (1951), a deriva genética irá resultar em diferenciação populacional substancial se $\mathrm{Nm}<1$ mas não se $\mathrm{Nm}>1$. Como a estimativa de fluxo gênico aparente foi bem menor que $1(0,317$, tabela 17$)$, pode-se inferir que a deriva está desenvolvendo um papel importante na formação da estrutura genética das populações estudadas, se for considerado que a seleção natural não tem um papel importante, como já discutido anteriormente (ítem 4.2). 
Tomando-se o fluxo gênico entre cada par de populações (tabela 18), observa-se que este é bem elevado entre as populações da Ilha dos Alcatrazes e Bertioga e bastante baixo tanto entre Alcatrazes e Bertioga quanto entre São Sebastião e Bertioga.

$\mathrm{O}$ valor de $\mathrm{Nm}$ calculado a partir da divergência genética reflete o fluxo gênico que ocorreu durante um longo período; ele não indica se está havendo fluxo gênico em determinado evento reprodutivo, mas estima os níveis de fluxo gênico que devem ter ocorrido no passado para produzir os padrões observados de estrutura genética. Assim, o alto $\mathrm{Nm}$, ao invés de fluxo gênico atual, pode indicar uma base genética mais estreita entre as populações da Ilha dos Alcatrazes e Bertioga do que entre Alcatrazes e São Sebastião ou mesmo entre as populações continentais, sugerindo que elas estivessem mais ligadas anteriormente ou que fossem originárias de uma população ancestral comum. Isto é coerente com a formação da população da Ilha dos Alcatrazes a partir de uma população anteriormente ligada à população de Bertioga, que permaneceu após a elevação do nível do mar depois da última glaciação, ou de uma população fundadora derivada da população de Bertioga. A população de S. Sebastião não deveria ter esta ligação com as outras populações, tendo uma ligação mais antiga com as outras populações e/ou uma origem a partir de poucos indivíduos e assim sofrido grandemente com efeitos de deriva.

Porém, se considerarmos que o $\mathrm{Nm}$ é realmente o resultado de fluxo gênico recente, as populações de Alcatrazes e Bertioga estariam trocando genes largamente, enquanto que a população de São Sebastião teria muito pouco fluxo gênico tanto com a população de Alcatrazes quanto com a de Bertioga. Isto parece ser um tanto improvável de ocorrer, ainda mais considerando que o fluxo gênico encontra-se dificultado pela grande distância existente entre as populações continentais e da Ilha (aproximadamente $30 \mathrm{~km}$ ). Além disso, não existem na Ilha dos Alcatrazes dispersores potenciais. Não existem mamíferos na Ilha, exceto morcegos, e as aves frugívoras são pequenas em relação ao tamanho da semente do jerivá, e residentes da Ilha, não realizando migração (MARTUSCELLI, comunicação pessoal). Deste forma, as possibilidades de fluxo gênico são bastante restritas. 


\subsection{Tamanho efetivo}

As estimativas de tamanho efetivo para as populações, considerando os dados de progênies, são mostradas na tabela 19.

\begin{tabular}{|c|c|c|}
\hline & $\hat{\mathbf{N}}_{\mathbf{e}}$ & $\mathbf{N}$ \\
\hline Alcatrazes & 19,72 & 88 \\
\hline Bertioga & 9,65 & 100 \\
\hline São Sebastião & 19,05 & 93 \\
\hline total & 5,26 & 281 \\
\hline
\end{tabular}

Todos os valores de tamanho efetivo foram bastante baixos, sendo bem menores que o número de indivíduos (tabela 19), porém isto é esperado dado o parentesco entre as plântulas das progênies.

O tamanho efetivo das populações da Ilha dos Alcatrazes e de Bertioga foram maiores que o da população de Bertioga. Eles foram bastante baixos, mas aproximaramse bastante do valor correspondente para famílias de meios irmãos, já que neste caso, $\mathrm{Ne}$ $=4 \mathrm{~F}$, sendo $\mathrm{F}$ o número de famílias (VENCOVSKY, 1987), e assim Ne $=4 \times 5=20$. Isto indica que estas progênies se aproximam muito de famílias de meios irmãos, sendo suas plântulas o resultado do cruzamento com pais diferentes. Já a população de Bertioga se aproxima bastante de progênies de irmãos completos (mesmos pai e mãe). Para irmãos completos, $\mathrm{Ne}=2 \mathrm{~F}$ (VENCOVSKY, 1987), e em Bertioga, $\mathrm{Ne}=2 \times 5=10$. Assim, o baixo valor de tamanho efetivo para esta população pode ser devido ao cruzamento biparental. 
$\mathrm{O}$ alto $\hat{\theta}_{\mathrm{F}}$ da população de Bertioga (tabela 20), que indica uma maior semelhança dentro das famílias, é coerente com esses resultados de tamanho efetivo. A população de Bertioga apresentou também $\hat{\theta}_{\mathrm{F}}^{\prime}$ (tabela 20) próximo do valor de irmãos completos $(0,250$, VENCOVSKY, 1992). O cruzamento preferencial já tinha sido indicado por $\hat{\theta}_{\mathrm{F}}^{\prime}$, considerando as três populações, discutido no ítem 4.4.(estrutura genética, tabela 9), mas agora pode ser considerado oriundo apenas da população de Bertioga.

Tabela 20: $\hat{\theta}_{\mathrm{F}}$ e $\hat{\theta}_{\mathrm{F}}^{\prime}$ para três populações naturais de Syagrus romanzoffiana. Dados a partir de progênies.

\begin{tabular}{|c|c|c|}
\hline & $\hat{\theta}_{\mathrm{F}}$ & $\hat{\theta}_{\mathrm{F}}^{\prime}$ \\
\hline Alcatrazes & 0,104 & 0,104 \\
\hline Bertioga & 0,241 & 0,242 \\
\hline São Sebastião & 0,109 & 0,109 \\
\hline
\end{tabular}

A tabela 21 mostra os tamanhos efetivos das populações considerando dados de indivíduos adultos. 
Tabela 21: Tamanho efetivo $\left(\hat{\mathrm{N}}_{\mathrm{e}}\right)$ e número de indivíduos $(\mathrm{N})$ de três populações naturais de Syagrus romanzoffiana, considerando dados de indivíduos adultos.

\begin{tabular}{lcl}
\hline \hline & $\hat{\mathbf{N}}_{\mathbf{e}}$ & $\mathbf{N}$ \\
\hline Alcatrazes & 29,66 & 30 \\
Bertioga & 21,61 & 20 \\
São Sebastião & 21,31 & 30 \\
total & 7,26 & 80 \\
\hline \hline
\end{tabular}

O tamanho efetivo para os dados de adultos foram bastante diferentes dos dados de progênies. As populações de Alcatrazes e Bertioga apresentaram um tamanho efetivo muito próximo ao número de indivíduos. Já para a população de São Sebastião, o tamanho efetivo foi inferior ao número de indivíduos. Esta diferença pode ser devida à menor variação genética desta última população.

\subsection{Considerações visando a conservação genética}

A deriva genética é geralmente inferida na literatura de isoenzimas a partir: (1) da distribuição aleatória dos alelos nas populações, com perda e fixação de alelos, (2) da diminuição da variação genética, principalmente de $P$, (3) da alta divergência interpopulacional e baixo endocruzamento intrapopulacional : (4) da ausência de correlação entre distância genética e distância geográfica. Estes fatores não provam que essas diferenças entre populações são devidas à deriva, mas sugerem que não existem razões fortes para se acreditar que as diferenças sejam devidas à qualquer outra coisa senão o acaso. 
As populações estudadas de Syagrus romanzoffiana apresentaram locos com freqüências alélicas diferentes para diferentes populações, com perda e fixação de alelos bem como alelos raros. A população de São Sebastião, que é provavelmente a população de menor tamanho, apresentou uma menor proporção de locos polimórficos. A estrutura populacional foi marcada por uma alta divergência entre as populações e baixo endocruzamento dentro delas. Assim, a deriva genética pode ser considerada um fator evolutivo de grande influência na determinação da estrutura genética das populações de S. romanzoffiana estudadas. Para a espécie, a deriva genética pode estar associada à sua distribuição disjunta. $\mathrm{O}$ isolamento das populações favoreceria a atuação de eventos aleatórios, se considerarmos que os ambientes aos quais as populações estão sujeitas são homogêneos.

O conhecimento da distribuição espacial da espécie em outras áreas de ocorrência seria importante para verificar se a disjunção e sua associação com alta divergência interpopulacional é o padrão mais comumente encontrado na espécie ou se constitui alguma característica particular (como por exemplo nas áreas mais marginais de ocorrência). Se este for o padrão, a espécie pode ser considerada um modelo de espécie arbórea tropical que apresenta populações disjuntas, combinada com alta divergência interpopulacional e baixo endocruzamento intrapopulacional

Em relação às populações de Syagrus romanzoffiana estudadas, a grande divergência interpopulacional e o pequeno endocruzamento intrapopulacional revela que para a conservação da espécie seria necessário considerar-se um grande número de populações para abarcar toda a variação existente.

Devido à alta divergência populacional, a coleta de germoplasma deve adotar um maior esforço amostral em relação às populações do que em relação a indivíduos dentro de populações. A coleta de sementes poderia considerar um maior número de matrizes e um menor número de sementes de cada matriz, já que a variação entre famílias foi alta.

Para as populações de $S$. romanzoffiana de Alcatrazes e Bertioga, o tamanho efetivo almejado para a conservação genética pode ser considerado equivalente ao número de indivíduos. Para a população de São Sebastião o número de indivíduos deve ser um pouco superior $(\sim 30 \%)$. 
Um melhor conhecimento dos tamanhos populacionais seriam necessários para a confirmação das hipóteses levantadas por este trabalho. Estudos de biologia reprodutiva seriam também muito importantes para elucidar a atuação do fluxo gênico na estrutura genética da espécie estudada. O conhecimento da polinização e dispersão de sementes poderiam auxiliar na compreensão da maior semelhança entre as populações da Ilha dos Alcatrazes e de Bertioga do que entre as populações continentais. Fundamental seria o estudo de análise de paternidade com um marcador potente (por exemplo microsatélites), para verificar a magnitude do fluxo gênico corrente entre as populações.

As populações insulares são erroneamente consideradas de baixo valor para conservação por possuírem tamanho reduzido, baixa diversidade genética e alta endogamia, possuindo assim uma alta probabilidade de extinção. Contudo, o isolamento pode proporcionar qualidades biológicas únicas e também muito importantes para estudos evolutivos. A população de Syagrus romanzoffiana da Ilha dos Alcatrazes apresenta um tamanho populacional grande, panmixia, alogamia e considerável diversidade genética, possuindo assim um grande potencial para permanecer na Ilha por muitas gerações. Ela possui uma alta variação genética, tamanho populacional relativamente grande, alta densidade populacional e alelos exclusivos, sendo dotada de uma combinação singular de características que a faz destacar-se de outras populações, conferindo-lhe um valor único para a conservação genética 


\section{CONCLUSÕES}

A partir dos resultados encontrados para progênies de três populações naturais estudadas de Syagrus romanzoffiana, pode-se concluir que:

Os índices de diversidade genética não foram diferentes entre as populações, exceto a proporção de locos polimórficos;

A estrutura genética foi caracterizada pela existência da maior parte da variação genética entre as populações e uma menor parte dentro de populações;

As populações da Ilha dos Alcatrazes e de Bertioga apresentaram-se pouco divergentes, sugerindo a ocorrência de uma base genética comum; já as populações de Alcatrazes e São Sebastião mostraram-se mais divergentes entre si;

A espécie mostrou alogamia preferencial no evento reprodutivo estudado;

A população de Alcatrazes e de São Sebastião mostraram tamanhos efetivos de progênies maiores do que a população de Bertioga, e próximo dos valores de meiosirmãos;

A população de Alcatrazes e de Bertioga mostraram tamanhos efetivos de adultos maiores do que a população de São Sebastião, e próximos do número de indivíduos; 
A deriva genética ficou evidenciada a partir da distribuição aleatória dos alelos (alelos exclusivos, fixação e perda de alelos, diferenças de freqüências gênicas entre populações), da alta divergência interpopulacional e pequeno endocruzamento dentro das populações, e do fluxo gênico aparente menor do que 1. 


\section{REFERÊNCIAS BIBLIOGRÁFICAS}

ALFENAS, A.C., PETERS, I, BRUNE, W. e PASSADOR, C.G.. 1991. Eletroforese de proteínas e isoenzimas de fungos e essências florestais. Viçosa: Universidade Federal de Viçosa. $242 \mathrm{p}$.

ALVAREZ-BUYLLA, E.R., e GARAY, A.A. 1994. Population genetic structure of Cecropia obtusifolia, a tropical pioneer tree species. Evolution, 48, 2, p.437-453.

ALVES, M.R.P e DEMATTÊ, M.E.S.P. 1987 Palmeiras. Características botânicas e evolução. Campinas: Fundação Cargill.129 p.

BARRETT S.C.H. e HUSBAND, B.C. 1990. The genetics of plant migration and colonization. In: BROWN, A.D.H., CLEGG, M.T., KAHLER, A.L. e WEIR, B.S. (eds). Plant Population Genetics, Breeding and Genetic Resources. Suderland: Sinauer associates. p. 254-277.

BAWA, K.S. 1974. Breeding systems of tree species of a lowland tropical community. Evolution, 28, p.85-92.

BAWA, K.S. 1992. Mating systems, genetic differentiation and speciation in tropical rain forest plants. Biotropica, 24 (2b), p.250-55.

BAWA, K.S., PERRY, D.R. e BEACH, J.H. 1985. Reproductive biology of tropical lowland rais forest trees. Am. J. Bot., 72 (3), p. 331-345.

BROWN, A.H.D. 1978. Isozymes, plant population genetic structure and genetic conservation. Theoretical and Applied Genetics, 52, p. 145-57.

BROWN, A.H.D. 1990. Genetic Characterization of Plant Mating Systems. In: BROWN, A.D.H., CLEGG, M.T., KAHLER, A.L. e WEIR, B.S. (eds). Plant Population Genetics, Breeding and Genetic Resources. Suderland: Sinauer associates. p. 145-162.

BUTCHER, P.A, MORAN G.F e PERKINS, H.D. 1998. RFLP diversity in the nuclear genome of Acacia mangium. Heredity, 81, p.205-213.

BUTCHER, P.A.; BELL, J.C. e MORAN. G.F.1992. Patterns of genetic diversity and nature of breeding system in Melaleuca alternifolia (Myrtaceae). Aust. J. Bot., 40, p. 365-75.

CLEGG, M.T. 1990. Measuring plant mating systems. Bioscience, 30 (12), p.81-818.

COIMBRA-FILHO, A.F. 1976. Leontopithecus rosalia chrysopygus (Mikan, 1823), o mico leão do Estado de São Paulo (Callitrichidae-Primates). Revista do Instituto Florestal, 10, p.1-36.

CROW J.F.e AOKI, K. 1984. Group selection for a polygenic behavioral trait: estimating the degree of population subdivision. Proceedings of the National Academy of Sciences of the U.S.A., 81, p. 6073-6077. 
COCKERHAM, C.C.1969. Variance of gene frequencies. Evolution, 23, p.72-84.

COCKERHAM, C.C. e WEIR, B.S. 1993. Estimation of genne flow from F-Statistics. Evolution, 47 (3), p.885-863.

COOK, I.A. e LADIGES, P.Y. 1998. Isozyme variation in Eucalyptus nitens and E. denticulata. Aust. J. Bot., 46, p.35-44.

CROW, J.F e KIMURA, M. 1993. Introduction to population geneticd theory. New York: Harper \& Row. 591 p.

DOWE, J.L.;BENZIE, J.; e BALLMENT, E. 1997. Ecology and genetics of Carpoxylon macrospermum $\mathrm{H}$. Wendle. \& Drude (Arecaceae), an endangered palm from Vanuatu. Biological Conservation, 79, p. 205-216.

EGUIARTE, L.E., PEREZ-NASSER, L. e PIÑERO, D. 1992. Genetic structure, outcrossing rate and heterosis in Astrocaryum mexicanum (tropical palm): implications for evolution and conservation. Heredity, 69, p. 217-228.

EL-KASSABY, Y.A.; RUSSELL, J. e RITLAND, K. 1994. Mixed mating in na experimental population of western red cedar, Thuja plicata. The Journal of Heredity, 85 (3), p. 227-231.

ELLSTRAND, C.N. e ELAM, D.R. 1993. Population genetic consequences of small populatin size: Implications for plant conservation. Annu. Rev. Ecol. Syst., 24, p. $217-42$.

FALK, D.A e HOLSINGER, K.E. (eds). 1991. Genetics and conservation of rare plants. New York: Oxford University Press.

FRANKEL, O.H. e SOULÉ, M.E. 1981. Conservation and Evolution. Cambridge: Cambridge University Press. 329 p.

FUTUYMA, D.J. 1992. Biologia Evolutiva. 2 ed. Ribeirão Preto: Sociedade Brasileira de Genética/CNPq. 646 p.

GANDARA, F.B. 1996. Diversidade Genética, Taxa de Cruzamento e Estrutura Espacial dos Genótipos em uma População de Cedrela fissilis Vell. (Meliaceae). Campinas, IB, UNICAMP. 69 p. Dissertação (Mestrado em Ciências).

GE, S.; HONG, D.; WANG, H.; LIU, Z e ZHANG, C. 1998. Population genetic structure and conservation of an endangered conifer, Cathaya argyrophylla (Pinaceaea).Int. J. Plant Sci.,159 (2), p.351-357.

GEBUREK, T. 1997. Isozymes and DNA markers in gene conservation of forest trees. Biodiversity and Conservation, 6, 1639-1654. 
GONCHARENKO, G.G., SILIN A.E. e PADUTOV, V.E. 1994. Allozyme variation in natural populations of Eurasian pines. III. Population structure, diversity, differentiation and gene flow in central and isolated populations of Pinus sylvestris in Eastern Europe and Siberia. Silvae Genetica, 43 (2-3), p. 119-132.

GUIX, J.C. e RUIZ, X. 1995. Toucans and thrushes as potential disperses of seedpredatory weevil larvae in southeastern Brazil. Can. J. Zool., 73, p.745-748.

GUIX, J.C. e RUIZ, X. 1997. Weevil larvae dispersal by guans in southeastern Brazil. Biotropica, 29 (4), p. 522-525.

HALL,P., ORREL,L.C. e BAWA, K.S. 1994. Genetic diversity and mating system in a topical tree, Carapa guianensis (Meliaceae). .American Journal of Botany, 80 (9):1104-1111.

HAMRICK, J.L. 1990. Isozymes and the analysis of genetic struture in plant populations. In: SOLTIS, D. E. e SOLTIS, P.S. (eds). Isozymes in Plant Biology. London, Chapman and Holl Ltda. p. 87-105.

HAMRICK, J.L. e GODT, M.J.W. 1990. Allozyme diversity in plant species. In: BROWN, A.D.H., CLEGG, M.T., KAHLER, A.L. e B.S. WEIR (eds). Plant Population Genetics, Breeding and Genetic Resources. Suderland: Sinauer associates. p. 43-63.

HAMRICK, J.L. e LOVELESS, M.D. 1986. Isozyme variation in tropical trees: Procedures and preliminary results. Biotropica,18 (3), p. 201-207.

HAMRICK, J.L. e MURAWSKY, D.A. 1990. The breeding structure of tropical tree populations. Plant Species Biol., 5, p.157-165.

HAMRICK, J.L. e MURAWSKY, D.A. 1991. Levels of allozyme diversity in populations of uncommon neotropical tree species. Jou rnal of Tropical Ecology, 7, p. 395-399.

HAMRICK, J.L, LINHART, Y.B. e MITTON, J.B. 1979. Relationships between life history characteristics and electrophoretically-detectable genetic variation in plants. Ann. Rev. Ecol. Syst., 10, p. 173-200.

HAWLEY, G.J. e DeHAYES, D.H. 1994. Genetic diversity and population structure of red spruce (Picea rubens). Can. J. Bot., 72, p. 1778-1786.

HOUSE, A.P. e BELL, J.B. 1994. Isozyme variation and mating system in Eucalyptus urophylla S.T. Blake. Silvae Genetica, 43 (2-3), p. 167-176. 
KAGEYAMA, P.Y. 1990. Genetic structure of tropical tree species of Brazil. In: BAWA, K.S. e HADLEY, M. (eds). Reproductive ecology of tropical forest plants. Paris: UNESCO/The Parthenon Publishing Group. p. 375-387.

KAGEYAMA, P.Y e CASTRO, C.F.A. 1989. Sucessão secundária, estutura genética e plantações de espécies arbóreas nativas. IPEF, 41-42, p. 83-93.

KAGEYAMA, P.Y. e GANDARA, F.B. 1993. Dinâmica de populações de espécies arbóreas: Implicações para o manejo e a conservação. III Simpósio de Ecossistemas da Costa Brasileira, vol 2. ACIESP.

KEPHART, S.R. 1990. Starch gel electrophoresis of plant isozymes: a comparative analysis of techniques. Am. J. Bot., 77 (5), p. 693-712.

KITAMURA, K. e RAHMAN, M.Y.B.A. 1992. Genetic diversity among natural populations of Agathis borneensis, a tropical rain forest conifer from Brunei Darussalam, Boreo, Southeast Asia. Can. J. Bot., 70, 1945-1949.

KUSER, J.E., MEAGHER, T.R. SHEELY e WHITE, A. 1997. Allozyme frequencies in New Jersey and North Carolina populations of atlantic white-cedar, Chamaecyparis thyoides (Cupressaceae). Am. J. Bot., 84 (11), p. 1536-1541.

LACERDA, C.M.B. 1997. Diversidade genética por isoenzimas de populações naturais de aroeira (Myracrodruon urundeuva Freire, F \& M.F. Allemão) Anarcadiaceae no semi-árido. Piracicaba: LCF, ESALQ/USP. Dissertação (Mestrado em Ciências Florestais).

LEDIG, F.T. e CONKLE, M.T. 1983. Gene diversity and genetic structure in a narrow endemic, torrey pine (Pinus torreyana Parry ex Carr.). Evolution, 37 (11), p. 79 85.

LEDIG, F.T, CONKLE, M.T., BERMEJO-VELÁZQUEZ, B., EGUILUZ-PIEDRA, T., HODGSKISS, P.D., JOHNSON,D.R. e DVORAK, W.S. 1999. Evidence for anextreme bottleneck in a rare mexican pinyon: genetic diversity, disequilibrium, and the mating system in Pinus maximartinezii. Evolution, 53 (1), p. 91-99.

LEITÃo FILHO, H.F. 1993. Ecologia da Mata Atlântica em Cubatão. Campinas: Editora da Universidade Estadual Paulista. Editora da Universidade de Campinas.

LEPSCH-CUNHA, N. 1996. Estrutura genética e fenologia de espécies raras de Couratari spp. (Lecythidaceae) na Amazônia Central. Piracicaba: LCF, ESALQ/USP.147 p. Dissertação (Mestrado em Ciências Florestais).

LEWIS, P. e ZAYKIN, D. 1999. Genetic Data Analysis. Versão 1.0 para Windows 3.1. (Não publicado). 
LOVELESS, M. D. e HAMRICK, J.L. 1984. Ecological determinants of genetic structure in plant populations. Ann. Rev. Ecol. Syst., 15, p. 65-95.

LOPES, C.R., REIS, S.F., FERREIRA, M.A. e MORETZSOHN, M.C. 1992. Genetics of the genus Acrocomia (Palmae). III Microgeographical genetic variability in isozyme frequencies. J. Genet. and Breed., 46, p. 9-14.

LORENZI,H. 1992. Árvores Brasileiras; Manual de Identificação e Cultivo de Plantas Arbóreas Nativas do Brasil. Nova Odessa: Editora Plantarum. 289 p.

LUEDERWALDT, H. e FONSECA, J.P. 1923. A Ilha dos Alcatrazes. Revista do Museu Paulista, São Paulo. V.13, p. 439-513.

MAIA, A.A, SERRAN, F.P, FERNANDES, H.Q.B.F., OLIVEIRA, R.R., OLIVEIRA, R.F. e PENNA, T.M.P.A. 1987. Inferências faunísticas por vestígios vegetais: III: Inter-relações do caxinguelê (Sciurus aestuans ingramii, Thomas 1901) com a palmeira baba-de-boi (Syagrus romanzoffiana (Chamisso) Glassman). Atas da Sociedade Botânica do Brasil, 3 (7), p.89-94.

MALTEZ, H.M. 1997. Estrutura genética de aspidosperma polineuron Muell. Arg. Apocynaceae (peroba rosa) em um floresta estacional semidecidual no Estado de São Paulo. Campinas: IB, UNICAMP. 132 p. Dissertação (Mestrado em Ciências).

MAMEDE-COSTA, AC. e GODOI, S. 1998. Consumption of Syagrus romanzoffiana (Arecaceae) fruits, by black lion tamarins (Leontopithecus chrysopygus) in southeastern Brazil. Mammalia, 62 (2), p. 310-313.

MANTOVANI, W. 1993. Estrutura e Dinâmica da Floresta Atlântica na Juréia, Iguape - SP. Tese de Livre Docência, I.B./U.S.P., São Paulo.

MANTOVANI, W. 1992. A vegetação sobre a restinga em Caraguatatuba,SP. In: Congresso Nacional sobre Essências Nativas.2., São Paulo, 1992. Anais. São Paulo, Intituto Florestal - SMA. Revista do Instituto Florestal, 4 (1), p.139-44.

MARUYAMA, T. e FUERST, P.A. 1984. Population bottlenecks and nonequilibrium models in population genetics. I. Allele numbers when populations evolve from zero zero variability. Genetics, 108, p. 745-63.

MILLAR, C.I. e LIBBY, W.J. 1991. Strategies for conserving clinal, ecotipic and disjunct population diversity in widespread species. In: FALK, D.A e HOLSINGER, K.E. Genetics and conservation of rare plants. New York: Oxford University Press. p. 149-170. 
MILliGAN, B.G., LEEBENS-MACK, J. e STRAND, A.E. 1994. Conservation genetics: beyond the maintenance of marker diversity. Mol. Ecol., 3, p. 423-434.

McCLENAGHAN, L.R. e BEAUCHAMP, A.C. 1986. Low genic differentiation among isolated populations of the california fan palm (Washingtonia filifera). Evolution, 40 (2), p. 315-322.

MORAES, M.L.T. 1992. Variabilidade genética por isoenzimas e caracteres quantitativos em duas populações naturais de aroeira Myracroduon urundeuva F.F. \& M.F. Allemão - Anacardiaceae (Syn: Astronium urundeuva (Fr. Allemão) Engler). Piracicaba: LGN, ESALQ/USP. 139p. Tese (Doutorado em Agronomia)

MORAES, P.L.R. 1997. Estrutura genética de populações de Cryptocarya moschata Nees \& Martius ex Nees (Lauraceae). Rio Claro: IB, UNESP. 190 p. Tese (Doutorado em Ciências Biológicas).

MORAN, G.F. e HOPPER, S.D. Genetic diversity and the insular population structure of the rare granite rock species, Eucalyptus caesia Benth. Aust. J. Bot., 31, p.16172.

MORAN, G.F., MUONA, O. e BELL, J.C. 1989. Acacia mangium: a tropical forest tree of the coastal lowlands with low genetic diversity. Evolution, 43 (1), p. 231-235.

NEI, M. 1978. Estimation of a average heterozigosity and genetic distance from a small number of individuals. Genetics, 89. p 583-590.

NEI, M., MARUYAMA, T.e CHAKRABORTY, R. 1975. The bottleneck effect and genetic variability in populations. Evolution, 29, p.1-10.

ODASZ, A.M. e SAVOLAINEN, O. 1996. Genetic variation in populations of the arctic perennial Pedicularis dasyantha (Scrophulariaceae), on Svalbard, Norway. Am. J. Bot., 83 (11), p. 1379-1385.

O’MALLEY, D.M., BUCKLEY, D.P., PRANCE,G.T. e BAWA, K.S. 1988. Genetics of Brazil nut (Bertholletia excelsa Humb. \& Bompl.:Lecithidaceae).2. Mating system. Theoretical and Applied Genertics, 76. p. 929-932.

PAIVA, J.R. Variabilidade enzimática em populações naturais de seringueira [Hevea brasiliensis (Willd. ex Adr. De Juss.) Müell. Arg.]. Piracicaba: LGN, ESALQ/USP. 145p. Tese (Doutorado em Agronomia).

PASCHOAL, M. e GALLETTI, M. 1995. Seasonal food use by the neotropical squirrel Sciurus ingrami in southeastern Brazil. Biotropica, 27 (2), p. 268-273. 
PÉREZ-NASSER, N; EGUIARTE, L.E. e PIÑERO, D. 1993. Mating system and genetic structure of the distylous tropical tree Psychotria faxlucens (Rubiaceae). American Journal of Botany, 80 (1), p. 45-52.

PETERS, G.B., LONIE, J.S. e MORAN, G.F. 1990. The breeding system, genetic diversity and pollen sterility in Eucalyptus pulverulenta, a rare species with small disjunct populations. Aust. J. Bot., 38, 559-70.

POMPÉIA, S.L., PEREIRA, A., ROSSI, L., AIDAR, M.P.M., MORAES, R.P. e SANTOS, R.P. 1993. A Vegetação da Ilha dos Alcatrazes - São Paulo. III Simpósio de Ecossistemas da Costa Brasileira. vol 2. ACIESP.

QIU, Y. e PARKS, C.R. 1994. Dispariry of allozyme variation levels in three Magnolia (Magnoliaceae) species from the southeastern United States. Am. J. Bot., 81 (10), p. 1300-1308.

RAJORA, O.M.; DEVERNO, L.; MOSSELER, A. e INNES, D.J. 1998. Genetic diversity and population structure of disjunct Newfoundland and central Ontario populations of eastern white pine (Pinus strobus). Can.J.Bot., 76, p. 500-508.

REIS, M.S. Distribuição e dinâmica da variabilidade genética em populações naturais de palmiteiro (Euterpe edulis Martius). Piracicaba: LGN, ESALQ/USP. 144p. Tese (Doutorado em Agronomia).

REITZ, P.R.1974. Palmeiras. In: REITZ, P.R.(ed.) - Flora Ilustrada Catarinense. p. 143-51

RITLAND, K. 1997. Multilocus mating system program. MLTR. Version 1.1. University of Toronto, Canadá. (não publicado).

RITLAND, K. e EL-KASSABY, Y.A. 1985. The nature of inbreeding in a seed orchard of Douglas fir as shown by na efficient multilocus model. Theoretical and Applied genetics, 71 (3), p374-384.

RITLAND, K. e JAIN, S. 1981. A model for the estimation of outcrossing rate and gene frequencies using $n$ independent loci. Heredity, 47 (1), p. 35-52.

ROCHA, O.J. e LOBO, J.A. 1996. Genetic variation and differentiation among five populations of the guanacaste tree (Enterolobium cyclocarpum Jacq.) in Costa Rica. Int. J. Plant Sci., 157 (2), p. 234-239.

SANTOS, E.M.G. 1994. Ecologia da polinização, fluxo de pólen e taxa de cruzamento em Bauhinia forficata Link. (Caesalpinaceae). Piracicaba: LGN, ESALQ/USP. 114p. Dissertação (Mestrado em Agronomia). 
SCANDALIOS, J.G. 1969. Genetic control of multiple molecular forms of enzymes in plants. Biochemical Genetics, 3, p.37-79.

SEBBEN, A.M. 1997. Estrutura genética de subpopulações de Genipa americana L. (Rubiaceae) a partir de isoenzimas. Piracicaba: LCF, ESALQ/USP. Dissertação (Mestrado em Ciências Florestais).

SEOANE, C.E.S. Efeitos da fragmentação florestal sobre a estrutura genética de populações de Esenbeckia leiocarpa Engl. - guarantã- um exemplo de espécie arbórea tropical de distribuição agregada. Piracicaba: LCF, ESALQ/USP. 80 p. Dissertação (Mestrado em Ciências Florestais).

SHAPCOTT, A. 1998. The genetics of Ptychosperma bleeseri, a rare palm from the Northern Territory, Australia. Biological conservation, 85, p. 203-209.

S.M.A. 1989. Áreas Naturais sob Proteção no Estado de São Paulo. São Paulo, Secretaria do Meio Ambiente.

S.M.A.1996. Atlas das Unidades de Conservação Ambiental do Estado de São Paulo. Parte I - Litoral. Secretaria do Meio Ambiente e Companhia Energética de São Paulo.

SOEJIMA, A., MAKI, M e UEDA, K. 1998. Genetic variation in relic and isolated populations of Chionanthus retusus (Oleaceae) of Tsushima Island and the Tôno region, Japan. Genes Genet. Syst., 73, p. 29-37.

SOLBRIG, O.T. 1980. Genetic structure of plant populations. In: SOLBRIG O. T. (ed.). Demography and evolution in plant populations. Berkeley: University of alifornia Press. p. 49-65.

SOUZA, L.M.F.I. 1997. Estrutura genética de populações naturais de Chorisia speciosa St. Hil. (Bombacaceae) em fragmentos florestais na região de Bauru (SP)- Brasil. Piracicaba: LCF, ESALQ/USP. 76 p. Dissertação (Mestrado em Ciências Florestais).

SILIN, A.E. e GONCHARENKO, G.G. 1996. Allozyme variation in natural populations of Eurasian pines. IV. Population structure and genetic variation in geographically related and isolated populations of Pinus nigra on the Crimean Peninsula. Silvae Genetica, 45 (2-3), p.67-75.

SLATKIN, M. 1981. Estimating levels of gene flow in natural populations. Genetics, 99, p. 323-335. 
SWOFFORD, D.L. e SELANDER, R.B. 1989. Biosys-1. A computer program for analysis of allelic variation in population genetics and biochemical systematics. Release 1.7. Illinois: Natural History Survey. 43p.

TOMLINSON, P.B. 1979. Systematics and ecology of the Palmae. Ann. Rev. Ecol. Syst., 10, p.85-107.

TORGGLER, M.G., CONTEL, E.P.B. e TORGGLER, S.P. 1995. Isoenzimas. variabilidade genética em plantas. Ribeirão Preto: Sociedade Brasileira de Genética, SÉRIE MONOGRAFIAS N ${ }^{\mathrm{O}} 1.186 \mathrm{p}$.

VENCOVSKY, R. 1987. Tamanho efetivo populacional na coleta e preservação de germoplasma. IPEF 35, p. 79-84.

VENCOVSKY, R. 1992. Análise de variância de freqüências alélicas. Revista Brasileira de Genética, 17 (3), suplemento 1, p.349-351.

WRIGHT, S. 1931. Evolution in mendelian populations. Genetics, 16. p.97-159.

WRIGHT, S. 1965. The interpretation of population structure by F-statistics with special regard to systems of mating. Evolution, 19 (3), p.395-420.

YOUNG, A., BOYLE, T. e BROWN, T. 1996. The population genetic consequences of habitat fragmentation for plants. Tree, 11 (10), p. 413-418. 